\title{
La reconstrucción de Santa María de Ripoll por Martín Sureda y Elías Rogent (1880-1893)
}

\section{Historiografía e ideología en la afirmación del primer románico catalán como estilo nacional}

\author{
IGnACIO GonZÁLEZ-VARAS IBÁÑEZ ${ }^{1}$
}

\begin{abstract}
El redescubrimiento de la arquitectura románica en Cataluña en los últimos decenios del siglo xIx fue un acontecimiento cultural complejo (como episodio particular del historicismo medievalista) en el que se entrecruzaron motivaciones fuertemente ideológicas -la búsqueda de los orígenes de la tradición arquitectónica nacional representada en el primer románico-con razones estrictamente arquitectónicas en una doble versión, esto es, bien como recuperación arqueológica de esta arquitectura a través de la restauración, o bien -en una segunda instancia-como estilo susceptible de adoptarse para las construcciones contemporáneas, generando un interesante "neorrománico". Todo este cúmulo de valores es susceptible de asociarse a un representativo monumento catalán que aparece vinculado a la trayectoria de uno de los arquitectos neomedievalistas más activos durante último tercio del siglo XIX: se trata de la reconstrucción del Monasterio de Santa María de Fipoll a partir de la intervención de Elías Rogent y Amat (1821-1897) ². Este carácter sumamente emblemático de
\end{abstract}

\footnotetext{
1 Real Colegio de España. Universidad de Bolonia (Italia).

2 La importante personalidad de Elías Rogent, figura clave para comprender el desarrollo arquitectónico neomedievalista en Cataluña en los momentos previos a la gestación del Modernismo, es conocida especialmente a partir del Catálogo de la Exposición monográfica dedicada a Rogent en 1986: P. Hereu PAYET. L'Arquitectura d'Elias Rogent. Barcelona, 1986. pp.16-20. De este autor véase igualmente, P. HEREU I PAYET. Vers una arquitectura nacional. Barcelona, 1987. Los estudios de Hereu completan y sistematizan apuntes anteriores de B. BASSEGODA I AMIGó. “El arquitecto Elias Rogent». Associació d'Arquitectes de Catalunya. Barcelona, 1929 y B. BASsEgoda I MustÉ. "Elías Rogent, nuestro primer director». Algunos ensayos sobre técnica edificatoria. Barcelona, 1975. Javier Hernando, dentro de su evaluación global de la arquitectura española del siglo XIX,
} 
Santa María de Ripoll -en la complementariedad de perfiles ideológicos y estrictamente arquitectónicos y como punto de partida de buena parte de intervenciones posteriores en la arquitectura románica catalana- nos lleva a centrarnos en este monumento para ejemplificar lo que supuso una restauración sumamente característica de los criterios de intervención sostenidos en el siglo xIX, donde la restauración se acaba disolviendo en la reconstrucción $^{3}$, ejemplo capital para documentar la historia de la restauración arquitectónica en España durante el siglo xIX, como he tenído ocasión de tratar más detenidamente en otros escritos ${ }^{4}$.

En las páginas siguientes, consideraremos el proceso de restauraciónreconstrucción del Monasterio de Ripoll en una triple acepción significativa: en primer lugar, en cuanto al perfil ideológico subyacente en este proceso arquitectónico (captación emocional del pasado o uso pragmático de la Historia) que actúa como estructura profunda del redescubrimiento del románico catalán; en segundo lugar, se podrá verificar la incidencia concreta de las premisas ideológicas e historiográficas sobre la fábrica, asistiendo al "resurgimiento arquitectónico» del Monasterio de Santa María de Ripoll, donde se manifestará una figura hasta ahora inédita, la del arquitecto Martín Sureda, autor de un proyecto general de reconstrucción del edificio, que fue finalmente ultimado por Elías Rogent, personalidad esta última a quien se ha venido atribuyendo la totalidad de la paternidad de los

concede a Rogent una importancia fundamental en el desarrollo arquitectónico de la segunda mitad del siglo, con una especial atención al edificio de la Universidad Literaria de Barcelona, obra crucial de Rogent proyectada en 1860, replanteada en 1862 e inaugurada en 1871, y calificada por Hernando como "ejemplo intachable de neomedievalismo"; este autor subraya igualmente las líneas generales -especialmente ideológicas - que confluyeron en la restauración del Monasterio de Santa María de Ripoll. J. Hernando. Arquitectura en España, 1770-1900. Madrid, 1989. pp.199-204 y pp. 295-296.

3 La reconstrucción del Monasterio de Santa María de Ripoll, por este carácter especial que reúne, ya ha recibido algún tratamiento bibliográfico precedentemente. P. NAVASCúES PALACIO la incluye en su artículo "La restauración monumental como proceso histórico: el caso español, 18001950". Curso de Mecánica y Tecnología de los edificios antiguos. COAM, 1987. Más detalles se encuentran en el estudio de A. González MORENo Y NAVARRO. "La inacabada reconstrucció patriòtica del monestir de Ripoll». Arrel. Barcelona, mayo 1986. n. ${ }^{\circ} 14$.

4 Cómo estudio global de la evolución doctrinal y proyectual de la restauración arquitectónica, tomando como punto de partida el historicismo medievalista decimonónico a través del análisis comparado con análogas experiencias francesas, inglesas, alemanas e italianas, véase I. GONZÁlEZ-VARAS IBÁNEZ. Restauración monumental en España en el siglo xIX. Valladolid, 1996. La restauración arquitectónica en España se concentró en dos procesos especialmente complejos y prolongados como fueron los efectuados sobre las fábricas góticas de las catedrales de León y Sevilla, donde se asistió a la formulación de un modelo teorético de interpretación racionalista de la arquitectura gótica, a los que he dedicado sendos estudios monográficos. La Catedral de León, (1859-1901). Historia y restauración. León, 1993 y La Catedral de Sevilla (1880-1900). El debate sobre la restauración monumental. Sevilla, 1994. 
proyectos de reconstrucción de Ripoll; $y$, por último, se considerará sumariamente la labor historiográfica desenvuelta sobre esta disposición ideológica previa (esto es, asumir el pasado desde las claves racionalizantes de la Historia), proceso que puede tener en Ripoll un decisivo punto de partida para culminar en la monumental obra de José Puig i Cadafalch que introduce una novedosa metodología «arqueológica» en el estudio de la arquitectura románica catalana.

\section{SANTA MARÍA DE RIPOLL COMO MONUMENTO CLAVE DEL NACIONALISMO CATALANISTA: LA UNIDAD DE ESTILO COMO EXIGENCIA IDEOLÓGICA}

La Iglesia de Ripoll es el "monumento histórico» por excelencia: el Monasterio fue concebido desde su origen $-\mathrm{y}$ utilizando la metodología rielgiana - con una voluntad rememorativa intencionada, como una obra ligada a las instituciones condales y destinada a perpetuar estos significados. La construcción y renovación del Monasterio -identificado con el momento histórico de formación de la identidad de Cataluña en la Edad Media- resume la memoria pura del catalanismo, como la esencia de la conciencia nacionalista reactivada en la segunda mitad del siglo XIX. Algunos referentes históricos - por otro lado bastante conocidos- son imprescindibles para entender el alcance ideológico que revistió la reconstrucción del Monasterio en el último tercio del siglo xix en conexión ideológica con La Renaixença ${ }^{5}$.

El Monasterio gerundense de Santa María de Ripoll fue fundado en un momento decisivo de la historia de Cataluña. La primera consagración de la Iglesia se realizó en el año 888 por Godmar, Obispo de Vic, y, según consta en el acta, el edificio fue edificado bajo la directa iniciativa del

5 La bibliografía tradicional que reconstruye documentalmente la historia del Monasterio de Santa María de Ripoll es la generada en el último tercio del siglo xix, cuando el monumento se reviste de esta preocupación por fundamentar históricamente los orígenes en la formación del pueblo catalán; en este sentido fueron decisivos los estudios dedicados a Ripoll por Pellicer i Pagès, elaborados simultáneamente al proceso de restauración del Monasterio. PELLICER I PAGĖs. Breve reseña de la visita hecha al Monasterio de Ripoll. Gerona. 1875 y Santa María del Monasterio de Ripoll. Mataró, 1888. Sobre Ripoll, véase asimismo, V. LAMPÉREZ Y ROMEA. Historia de la Arquitectura cristiana española de la Edad Media. Madrid, 1908. vol.Il; pp.318-325. JUNYENT. La basilica de Santa María del Monestir de Ripoll, 1032-1932 y "Notes inèdites sobre el monestir de Ripoll». Analecta Sacra Tarraconensia. (1933); vol.IX; pp.185-225. W.M. WHITEHILL. Spanish Romanesque Architecture of Elevent Century. Oxford, 1941. L'Art romànic a Catalunya. Segle XI. Barcelona, 1973 (trad. Josep Vallverdú). cap.IV; pp. 22-25. 
Conde Wifredo el Velioso y su mujer Winilda que dotaron al Monasterio de tierras, ornamentos y demás. A partir de este patrocinio condal, el Monasterio experimentó un rápido crecimiento, de tal manera que cada generación amplía el edificio precedente, teniéndose constancia de tres consagraciones más a partir del año 888: una segunda consagración en el año 935, protagonizada por el Abad Ennego y el Obispo Jorge de Vic, otra tercera en el 977, por el Abad Guidiscle y con la presencia de Oliba Cabreta, Conde de Besalú y Cerdeña, que remite a una Iglesia abovedada y con cinco ábsides como remate de una planta con cinco naves; sin embargo, el momento decisivo del Monasterio ripollés está vinculado a la poderosa personalidad del Abad Oliba, hijo del Conde Oliba Cabreta, que convirtió a Santa María Ripoll en un centro cultural de primer orden: Oliba consagra una cuarta y definitiva Iglesia, con un monumental transepto con siete ábsides, el 15 de enero del 1032, consagración que marca el fin de esta sostenida actividad arquitectónica ${ }^{6}$.

Con esta constante renovación y enriquecimiento del Monasterio de Santa María de Ripoll desde finales del siglo ix hasta el primer tercio del siglo XI, el Monasterio compendia en sus muros la época decisiva de la gestación del sentimiento nacional catalán. El peligro musulmán no inquietó excesivamente a Cataluña y Wifredo el Velloso impuso su soberanía en el país al tiempo que proclama su independencia sobre poder imperial franco. Ripoll se convierte en el foco donde se centralizan estas aspiraciones, como ha señalado claramente Whitehill ": "A él (a Wifredo) se debe la fundación de Ripoll, que más tarde se convertiría en el foco religioso e intelectual de Cataluña y se desarrollará al mismo ritmo que la conciencia nacional. Como el Escorial siete siglos más tarde, era ahora una acción de gracias para su fundador y un santuario para su dinastía en el futuro, porque se convirtió en el mausoleo de Wifredo y sus descendientes".

El siglo XIX se sintió heredero directo del momento histórico de afirmación nacionalista y de los valores de independencia y soberanía catalana que simbolizaba el Monasterio ripollés ${ }^{8}$. La construcción de una

\footnotetext{
- El Abad Oliba, como es sabido, fue igualmente Abad de San Miguel de Cuixá y Obispo de Vic, hasta su muerte en el 1046.

7 W.M. WHITEHILL. L'Art romànic a Catalunya. Segle XI. cap.IV; p.22.

\& Esta reivindicación -en sentido literal- de este período histórico tuvo su punto de partida con la actividad desarrollada por Prosper de Bofarull que, además de salvar buena parte de la biblioteca del Monasterio de Ripoll, inició la recuperación de este período histórico de formación de la conciencia nacional catalana. P. de BOfaruLL. Los condes de Barcelona vindicados. Barcelona, 1836; cinco años antes habia publicado PuJADEs su Crónica universal del principado de Cataluña. Barcelona, 1831.
} 
teoría de la «nación» de carácter burgués, liberal, tradicionalista o reaccionario, aunque coherente en su formulación básica, fue una exigencia intelectual y social dotada de una firme armadura teórica desde las primeras y profundas exposiciones de Herder acerca del historicismo nacionalista ${ }^{9}$. Los teóricos del siglo XIX reaccionaron rápidamente, especialmente en Alemania, contra el difuso y artificial concepto de nación difundido a partir de la Revolución Francesa -en cuanto construcción puramente política, jurídica o intelectual- ${ }^{10}$ : amparándose en el historicismo herderiano, la nación viene definida como la construcción natural por la que el pueblo se expresa como unidad a lo largo de la Historia, unicidad declarada por la participación de los lazos comunes de la etnia, la lengua y, en suma, de una tradición más o menos mitificada o reactiva que se proyecta en unos ideales y símbolos compartidos. La idea alemana de la nacionalidad fue rápidamente acogida por los autores románticos, incluso -en cuanto a su definición política- el nacionalismo europeo recibió un prematuro impulso con la labor desarrollada en las Cortes de Cádiz que elaboran la Constitución a partir de los conceptos de Nación y Soberanía Nacional. Böhl de Faber y Durán trataron de buscar en España el «espíritu propio» de nuestra nación, que en numerosos autores quedará identificado con «el espíritu cristiano» al retrotraer el germen nacional a la mitificada Edad Media, lo que creará la enorme complejidad de la problemática nacional en España, tema constantemente debatido hasta nuestros días, al remitirse algunas corrientes político-ideológicas —especialmente el carlismo - a la tradicional estructura medieval

9 La resistencia polémica contra la cultura francesa en Alemania - ya claramente declarada por Lessing en el requerimiento de un teatro burgués alemán (Hamburgische Dramaturgie, 1768) y en la superación del deísmo francés- se hizo aún más explícita después de manifestarse por doquier tanto el espectro contrarrevolucionario como la conmoción provocada por las invasiones napoleónicas; el enunciado de une idea de la nación alemana era la manera más contundente de reaccionar contra el cosmopolitismo ilustrado que aceptó sin complicaciones la Revolución francesa.

10 Tradicionalmente se ha afirmado que la ideología revolucionaria sfue totalmente ajena al principio o al sentimiento de nacionalidad; incluso se mostró hostil a él». M. BLOCK. "Nationalities, principle of». Cyclopedia of political science. New York, 1889. vol.ll, p.939. Si se puede hablar en el período revolucionario de una estructura nación-pueblo, no es por una identificación «nacional» a través de criterios étnicos, históricos - tradición-o lingüísticos, sino más bien, como ha señalado Pierre Vilar, por la representación del interés común contra los réditos particulares o nobiliarios, frente a los privilegios estamentales, en suma, una nación identificada con el nuevo citoyen como sujeto activo de la Historia. P. VILAR. «Sobre los fundamentos de las estructuras nacionales». Historia 16. Madrid, abril de 1978. Extra V, p.11. Un análisis interesante sobre la constitución y fluctuaciones del nacionalismo en la época contemporánea es el de E.L. HoBsBAWN. Nations and Nationalism since 1780. Cambridge, 1990. Naciones y nacionalismo desde 1780. La «grande nation" a la que aspiraba la ambición napoleónica tenía esta raigambre nacionalista, o más bien habría que decir «supra o internacionalista». 
de reinos independientes. Esta adherencia se produjo especialmente en la afirmación del catalanismo que acopló el nacionalismo a la religión ${ }^{11}$. El despertar del resurgimiento nacionalista en Cataluña mostró sus primeros brotes en la primera mitad de la centuria, cuando Aribau escribe su emblemática Oda a la patria en 1832; la presencia de José Casademunt Torrents (1804-1866) en la Escuela de Arquitectura de la Junta de Comercio de Barcelona a partir de 1836 propició la apertura hacia los estilos medievales - Casademunt, a pesar de su formación clásica, levantó los planos de la Iglesia "gótica» de Santa Catalina- consolidándose el catalanismo a partir de la restauración de los Juegos Florales en 1859 y el despegue de la Renaixença. Tras la reconstrucción de Santa María de Ripoll por Elías Rogent, el scriptorium monástico es estudiado por los eruditos catalanes de los primeros decenios del siglo $\mathrm{xx}$ como el núcleo creativo que produce las primeras manifestaciones culturales genuinamente catalanas: aunque la mayor parte de la biblioteca se perdió, los estudiosos catalanes emprendieron una trabajosa labor de reconstrucción del amplio espectro de producción cultural emanada de la escuela de Ripoll, pues ello suponía conectar directamente con los gérmenes de la cultura «nacional» y el reconocimiento de la singularidad catalana como pueblo en el más pleno sentido herderiano, es decir, como unidad espiritual poseedora de una raíces culturales únicas: con Ripoll se asocian los orígenes de la escritura catalana tras los estudios de Massó i Torrens ${ }^{12}$; esta labor filológica es completada por Nicolau d'Olwer que reconstruye la escuela poética de Ripoll ${ }^{13}$, mientras que

11 Especialmente a través de la labor desarrollada por "Grupo de Vic", encabezado por Jaime Balmes y el obispo Torrás y Bagés, con una justificación del orden social jerarquizado como imitación del orden natural, corporativo, cristiano y rural del Medioevo, posiciones trasladas a $L a$ Renaixença con Manuel Milá i Fontanals -que sostiene un revivalismo conservador en la línea nazarena- Marti d'Exala - próximo al «sentido común» balmesiano-y Llorens i Barbá -exaltador del espíritu nacional- como figuras más destacadas del "catalanismo". La exaltación nacionalista en Cataluña se difundió a través del periódico fundado por López Soler, El Vapor, la Oda a la Patria de Carlos Buenaventura Aribau y la recuperación de la lengua catalana a través de los Jocs Florals (1833-36). Una versión progresista en la década de 1830 fue la que se vehiculó a través de El propagador de la libertad, de carácter "anticristiano", que rechazaba el "romanticismo reaccionario" (Schlegel, Stäel y Böhl de Faber) o "conservador» (Rosa, Alcalá Galiano) y se afilia a la "versión liberal» (Hugo, Dumas y Heine). La reapertura de la Universidad de Barcelona en 1833 y esta reaparición del catalán como lengua literaria apuntalan un proceso romántico de cultivo y atención a lo local, genuino y propio.

12 MAssó 1 TORRENS. "Historiografia de Catalunya en Català durant l'època nacional". Revue Hispanique. 1906. vol.V; pp.487-491. También véase BEER. "Les manuscrits del monestir de Santa María de Ripoll». Boletín de la Real Academia de Buenas Letras de Barcelona; (trad. de Barnils). Barcelona, 1910, t.V.

13 N. D'OLWer. "L'escola poètica de Ripoll en els segles X-XIl". Anuari de I'Institut d'Estudis Catalans. Barcelona, 1915-1920; pp. 3-84. 
Higinio Anglés estudia la música litúrgica creada en el Monasterio ${ }^{14}$. Por los mismos años, José Puig i Cadafalch, como veremos, definió la arquitectura románica catalana como una escuela nacional con carácter propio.

La utilización ideológica del pasado para fundamentar en la Historia las reivindicaciones catalanistas se observa de modo simultáneo en otras manifestaciones artísticas, como puede ser el caso evidente y ejemplar (por su carga retórica) de la pintura de historia. Frente a la temática centralista que subrayaba los grandes temas de la independencia de España - la unidad nacional y la gestación del Imperio español como temas dominantes y recurrentes en la pintura oficial-, en Cataluña proliferó la pintura con un contenido histórico que recogía los episodios que habían contribuido a formar en el pasado la identidad nacional. La Edad Media era el referente de la nacionalidad catalana. El pasado se mitifica y adopta un tono legendario de exaltación ideológica, como portador de contenidos aún latentes y vivos en el presente ${ }^{15}$ : los "mártires» de la historia catalana, como el Conde de Urgell - condenado al destierro después de la proclamación de Fernando de Antequera como rey de Aragón en Caspe- o el Príncipe de Viana - muerto en la cámara alta del Palacio Real de Barcelona rodeado de la nobleza catalana - fueron recreados por pintores como Tamburini o Vicente Poveda; pero la temática histórica se remonta hasta el momento germinal de la identidad catalana durante el período de los condes: el célebre tema del Origen del escudo de Cataluña enlazaba con la mitificada figura de Wifredo el Velloso - con el cuadro prototípico de Claudio Lorenzale - y la afirmación de la independencia de Cataluña frente al poder imperial franco (similar, aunque lógicamente antagónico en intenciones, al episodio de Pelayo en Covadonga); en suma, como ha expresado Carlos Reyero, "en Cataluña se utiliza esa imagen como expresión combativa del catalanismo y no como mera variante pintoresca de orgullo local» ${ }^{16}$.

Esta ejemplaridad que asumía el período histórico medieval tuvo su símbolo arquitectónico en Santa María de Ripoll. El contexto histórico que dio lugar al Monasterio de ripollés, como vimos, nos informa claramente de la carga emocional que gravitaba en torno al monumento, panteón de los

14 H. ANGLẺs «La Musique aux $x$ et $x I$ siècles. L'École de Ripoll». La Catalogne à l'époque romane. pp. 157-179.

15 Véanse al respecto los estudios realizados por C. REYERo. Imagen histórica de España. Madrid, 1987 y La pintura de historia en España. Madrid, 1989. "Nacionalismo español y nacionalismos». cap.IV, pp.109-128.

16 C. ReYero. La pintura... p. 123. 
condes catalanes. Los estudios historiográficos que se emprenden sobre la arquitectura medieval lograron fundamentar con el rigor analítico del método histórico el carácter peculiarmente catalán de la arquitectura generada en este período.

El carácter nacionalista que adoptó la restauración-reconstrucción de Ripoll durante el siglo xIx tuvo su momento culminante con la nueva consagración del edificio el día 10 de julio de 1893, ceremonia que parecía rememorar las consagraciones realizadas durante la Edad Media, cuando Cataluña mostraba su independencia frente a los imperios circundantes. Este carácter ideológico ha sido claramente señalado por Vila y Tornos cuando afirma que en el Monasterio de Ripoll durante el siglo XIX "confluyen los intereses ideológicos de la Iglesia y del catalanismo conservador» 17. Este mismo autor se ha detenido en argumentar la ceremonia de apropiación ideológica del monumento, que tuvo su culminación en esta solemne ceremonia de consagración del edificio: una vez recuperada su plenitud formal, el monumento se recubrió de una rememorativa carga emocional nacionalista, con la presencia de altas personalidades eclesiásticas, sociales y políticas - contándose con los presidentes de la Unió y de la Lliga- que refrendaban la doble significación de esta «reintegración» del monumento: esto es, su recuperación material por medio de la reconstrucción de la ruina y su recuperación ideológica tras las destrucciones del liberalismo revolucionario con la consiguiente revitalización de una venerable tradición acumulada en la memoria histórica del monumento.

La recuperación del estado original del edificio tal como había sido en tiempos del Abad Oliba fue el propósito de la restauración arquitectónica. La destrucción del Monasterio -después de un accidentado ciclo de transformaciones - fue consecuencia del saqueo e incendio provocado el 9 de agosto de 1835. Los levantamientos provinciales de julio-agosto de ese año fueron protagonizados por el liberalismo revolucionario, fundamentado en la tumultuosa alianza entre la turba urbana, las milicias y los radicales locales; los disturbios se originaron en Aragón y desde allí se extendieron a Cataluña, que se convirtió en el foco más violento de las iras revolucionarias ${ }^{18}$. La destrucción del Monasterio de Ripoll fue una más de las desolaciones de centros religiosos, como por ejemplo ocurrió

17 F. VILA Y TORNOS. "Text anthistoricistes en el debat arquitectònic de la Catalunya del darrer quart del segle XIX". V Congreso del Comité Español de Historia del Arte. Barcelona, 1984.

${ }_{18}$ Esto explica la reacción encabezada por Francisco Piferrer, dentro de la ambiciosa empresa de Recuerdos y bellezas de España, que consideraba los movimientos revolucionarios como el agente destructor por excelencia del patrimonio monumental. 
igualmente con la casa carmelita de Riudoms, asaltada el 25 de julio, con el incendio dos días después de la cartuja de Scala Dei o el asalto al Monasterio de Poblet pocos días más tarde ${ }^{19}$. El resultado de estos acontecimientos revolucionarios provocaron el cierre de la mayoría de los conventos y monasterios hacia el mes de septiembre de 1835; el Gobierno de Juan Álvarez Mendizábal y su política desamortizadora trató de acabar con los vestigios del Antiguo Régimen, corroborando la supresión de todos los monasterios del reino, salvo El Escorial y Poblet, por el famoso Decreto de 11 de octubre de $1835^{20}$. Interesa señalar esta asociación de la destrucción del Monasterio de Ripoll con el radicalismo revolucionario, pues la recuperación del edificio llevaba latente una carga ideológica doble: por una parte la más palpable afirmación catalanista a la que se ha aludido, pero, por otro lado, esta reintegración del edificio se puede entender también como la aseveración conservadora que repudiaba el radicalismo liberal.

La labor conciliadora iniciada durante la etapa isabelina por el Grupo de Vic - con las figuras descollantes de Jaime Balmes y el Obispo Torrás y Bagés- fue la encargada de crear una sintesis ideológica moderada que trataba de armonizar las aspiraciones de la burguesía catalana con el orden social tradicional. Llorens i Barbá apela al espíritu nacional como base del desarrollo del pueblo catalán, espíritu que, siguiendo la formulación herderiana, se localiza en la Edad Media y, más concretamente, en el momento inicial en que surge esta conciencia en toda su pureza. El modelo jerárquico de la sociedad medieval fue evocado por el obispo Torrás, propugnando la acomodación del espiritualismo con el orden natural, cor-

19 El expediente de restauración del Monasterio de Poblet se encuentra en el Archivo General de la Administración del Estado en su Sección de Educación y Ciencia - a partir de ahora A.G.A. (E. y C.) - C. 8.218, Lg. 8.956, Exp. n. ${ }^{\circ} 7$. El expolio y destrucción del Monasterio de Poblet fue uno de los sucesos más vergonzosos y dramáticos del vandalismo destructor en España: después de sufrir una primera exclaustración en 1820, fue, como digo, a partir de 1835, cuando la destrucción y el abandono fue sistemático, con el forzado abandono del Monasterio por los monjes que no regresaron hasta pasado más de un siglo, en el año 1940. La fundación de la Comisión de Monumentos de Tarragona trató de atajar la devastación, si bien el Monasterio de Poblet no fue declarado Monumento Nacional hasta 1921. Sobre la restauración de Poblet, véase J. BAsSEgoda Nonel. Historia de las restauraciones de Poblet. Poblet, abril de 1983 y del mismo autor, "Neomedievalismo en Cataluña. La restauración del Monasterio de Poblet". Medievalismo y neomedievalismo en la arquitectura española. Ávila, 1990; pp.119-128.

${ }_{20}$ El estudio más completo sobre la extinción prácticamente total del clero regular es el de $\mathrm{M}$. Revuelta GonzÁlez. La exclaustración, 1833-1840. Madrid, 1976. Como estudio valorativo puede consultarse asimismo G. BARRAQUER. Las casas de religiosos en Cataluña durante el primer tercio del siglo $x I x$. Barcelona, 1906. 
porativo, rural y cristiano surgido en la Edad Media ${ }^{21}$. Manuel Milá i Fontanals traduce a la estética estas doctrinas espiritualistas en sus Principios de estética o teoría de lo bello, publicados en 1857. En el último tercio del siglo XIX se prolongan estas ideas que adquieren una más firme apoyatura de acción política que llevará a las reivindicaciones catalanistas autonómicas que perduraron hasta que fueron sofocadas durante la Guerra Civil española. La gestación de un sólido aparato intitucional en Cataluña para la restauración del patrimonio artístico fue paralelo a este proceso, modelándose con una potente carga reivindictiva ${ }^{22}$.

21 Este catalanismo conservador hacía remontar sus orígenes ideológicos a las estructuras económicas y sociales del feudalismo - fundamentadas en la posesión señorial y monástica de la tierra- que fueron las que produjeron el primer arte románico como «sub-escuela nacional»; estas estructuras y su vigencia eran también evocadas por José Puig i Cadafalch cuando buscaba las bases socioeconómicas que generaron la arquitectura románica aparecida en el momento de gestación de la conciencia nacional: "Ha muerto el imperio universal siendo sustituido por el régimen del feudalismo. (...) Es el sistema económico del comienzo de la Edad Media, como el actual de la propiedad rural del pais en el que rigen las viejas costumbres. Ha desaparecido la vida ciudadana antigua, sustituida por la vida del campo". J. PUIG I CADAFALCH. L'Architectura romànica a Catalunya. Barcelona, 1911. (edic.facs. Barcelona, 1983 -2 2 edic.-). p. 576 .

22 Y ello sería, como digo, producto de la evolución general de la problemática -en su confluencia de problemas teóricos, ideológicos, arquitectónicos y, en último término administrativos- común al resto de España donde, como venimos comprobando, la restauración arquitectónica no conoce su despegue definitivo hasta el último tercio del siglo. Para un planteamiento general de la restauración monumental en Cataluña, véase A. GonZÁLEZ y R. LACUESTA. 1380-1980. Sis segles de protecció del patrimoni arquitectónic de Catalunya. Barcelona, 1984. En Cataluña se emprendieron dentro de este clima favorable numerosas restauraciones como las llevadas a cabo en el Monasterio de Poblet por Francisco Barba y Masip, la del claustro del Monasterio de San Pedro de Galligans o las campañas para recuperar la Catedral Vieja de Lérida, por entonces ocupada por los militares. En la época de proliferación restauradora, esto es, los decenios que discurren a partir de 1870 , se acometieron las restauraciones de los monasterios de Montserrat, Camprodón y San Cugat del Vallés, entre otros procesos. La Diputación de Barcelona comenzó a incluir en sus presupuestos partidas destinadas a la restauración de monumentos desde el año 1873, con un acusado intento de apartarse de la tutela administrativa central; del mismo modo, una institución como el Institut d'Estudis Catalans sirvió de órgano asesor en el primer decenio del siglo xx, hasta crearse en el año de 1914 un organismo propio de Ja Diputación como fue el Servei de Catalogació i Conservació de Monuments, aún vigente. Otra institución vinculada en Cataluña con la tutela monumental fue la Academia de Bellas Artes de San Jorge de Barcelona, creada en 1850, requerida en ocasiones por la Comisión Provincial de Monumentos para redactar informes. La formación de un foco de arquitectos "medievalistas", centralizado en torno a la emblemática figura de Elías Rogent como Director de la Escuela de Arquitectura, posibilitó este fértil contacto con el patrimonio medieval, que derivará finalmente, como es sabido, en el Modernismo. A todo ello habria que sumar la iniciativa privada, muy destacada; la potente burguesía catalana se volcó en buscar su legitimidad histórica en el pasado, participando activamente en los procesos de restauración o terminación de las fábricas medievales, en suma, apoyando material e ideológicamente estas grandes empresas de resurrección del nacionalismo y el catolicismo en una simbiosis sumamente característica de la época de auge industrial del territorio catalán. El patrocinio del proyecto de fachada de la Catedral de Barcelona por el financiero y senador vitalicio Manuel Girona y Agrafel es suma- 
Estaba claro que esta fuerte carga ideológica que impregnaba al monumento requería un tipo de intervención aquitectónica que devolviera la Iglesia de Santa María de Ripoll a su antiguo esplendor. Se trataba de la vigencia a ultranza de ese valor rememorativo intencionado del que hablaba Aloïs Riegl, centrado en el propósito de «no permitir que ese momento se convierta nunca en pasado, de que se mantenga siempre presente y vivo en la conciencia de la posteridad" ${ }^{23}$; lógicamente esta perduración del monumento, de sus valores ideológicos, se interpreta desde el presente, esto es, como una proyección subjetiva del presente hacia esa memoria activa que representa el monumento, permitiendo de este modo su instrumentalización, pues, en definitiva, se trata, como apunta el propio Riegl, de un valor de contemporaneidad. La memoria es de este modo reactivada; es decir, la apelación a la memoria histórica acumulada en el monumento significó no sólo el reconocimiento de los hechos del pasado, sino el revivir efectivo de los mismos, el más puro "recordar» en el sentido primitivo del término, como reproducción de estados anteriores, de un momento anterior, o, mejor todavía, como una vivencia actual -el recuperar el edificio- que llevaba latente en su recóndita memoria todo el prestigio del pasado. El resultado de esta carga significativa actuando sobre el monumento - forma artística portadora de un latente y vigente contenido ideológico- se traduce desde el punto de vista arquitectónico - que es lo que más nos interesa señalar- en una reconstrucción en profundidad y orientada a recuperar la integridad formal del monumento - su unidad de estilo- para devolverlo a su estado de pureza originaria como una manera de afirmar la plenitud ideológica de los contenidos vinculados a sus fábricas.

mente representativa al respecto. En numerosas ocasiones el monumento histórico fue portador de una notable instrumentalización ideológica y se convirtió en emblema de las aspiraciones nacionalistas, de una identidad cimentada en el pasado, fomentándose estos procesos de terminación -Catedral de Barcelona-o reconstrucción -Ripoll- como actividades de signo reivindicativo, incluso suplantando en ocasiones a la administración estatal en la promoción de unos trabajos que fueron sometidos con suma reticencia a la supervisión de los organismos estatales. En todo ello, como decimos, latía la actividad desarrollada por La Renaixença que entre sus demandas incluyó la autonomía catalana en la tutela de su pasado monumental: dos instituciones tuvieron en este sentido un gran protagonismo, el ya citado Instituto de Estudios Catalanes, fundado en 1907, y las sociedades excursionistas, siendo sobre todo conocida la presidida por Antonio Aulèstia y Pijoan, la Associació Catalanista d'Excursions Científicas; Pijoan publicó un polémico artículo en La Renaixença el 16 de febrero de 1896 en que solicitaba vivamente el papel de las sociedades privadas como vehículo para suplir la ínacción de la administración oficial.

${ }^{23}$ A. RIEGL. Der moderne Denkmalkultus. Sein Wesen und seine Entstehung. Wien-Leipzig, 1903. El culto moderno a los monumentos. Caracteres y origen. Madrid, 1987. p. 67. 


\section{LA RECONSTRUCCIÓN ARQUEOLÓGICA DE SANTA MARIA DE RIPOLL POR SUREDA Y ROGENT}

El Monasterio de Santa María de Ripoll había sufrido un accidentado ciclo de transformaciones que alteraron considerablemente la primitiva Iglesia románica antes del saqueo e incendio del cenobio en el año 1835. Especialmente grave fue el terremoto del año 1428 -popularmente conocido como el de «la Candelera»- que dio en tierra con la bóveda de la nave central; la reconstrucción del abovedamiento se realizó con crucerías góticas (fig. 13), como puede observarse en el corte longitudinal de la nave mayor trazado por Martín Sureda (fig. 14), que representa los formeros y los enjarges de la nave central y las bóvedas góticas del ábside central y crucero antes de la reconstrucción de Rogent; el tramo abovedado del crucero aparece más detallado en el corte longitudinal del transepto (fig. 12) ${ }^{24}$. El Padre Villanueva visitó el Monasterio de Ripoll en el año 1806 y dejó testimonio escrito de esta disposición gótica de la nave central y crucero ${ }^{25}$. Pero la Iglesia sufrió otra intervención entre los años 1826 a 1830 realizada con los criterios dominantes por esos años, es decir, con un tratamiento arquitectónico indiferente hacia el estilo románico del edificio que condujo a la reducción del templo a tres naves, suprimiéndose las arcadas y apoyos de colaterales, tal como puede observase en la planta de la Iglesia trazada por el marqués de Dou antes de la restauración (fig. 1). El saqueo e incendio del 9 de agosto de 1835 provocó graves daños y pérdidas en el conjunto arquitectónico, que el abandono y desamparo del Monasterio en los decenios siguientes incrementaron aún más, como dan testimonio las expresivas fotografías tomadas por Elías Rogent antes de la reconstrucción (figs. 5, 13 y 23): desde la dispersión de los monjes en 1835, la ruina del edificio avanzó de modo incontenible durante cuarenta años, de tal modo que antes de comenzarse la reconstrucción estaba completamente derrumbada la bóveda central y colaterales y

24 Algunas de las claves de estas bóvedas las depositó Rogent en el claustro después de reconstruir la bóveda de cañón seguido. La aportación documental de Junyens recoge el asentamiento de 425 florines pagados en el año 1432 a Jaume Graell de Barcelona por construir la bóveda del altar mayor que sustituyó a la antigua cúpula románica. JUNYENS. "Notes inèdites..." (1933); esta bóveda de crucería sería imputada por Rogent como una de las causas principales del debilitamiento y ruina de los muros de la Iglesia.

25 Villanueva confirma la existencia de una iglesia de cinco naves y poca elevación, dando las medidas de 300 palmos catalanes para la longitud total de la iglesia y de 200 palmos para el crucero, con la división entre las naves colaterales por medio de pilares y columnas alternados, coincidiendo con la restauración en planta de Elías Rogent. VILLANUEVA. Viage literario a las iglesias de España. 1806. vol.VIII; pp. 25 y ss. 
tan sólo quedaban en pie la parte inferior de los muros de la nave, el crucero y los ábsides y una de las dos torres de los pies de la Iglesia; el claustro ofrecía una crujía totalmente arruinada y graves deterioros en las restantes.

Los cuatro decenios que habían transcurrido desde la devastación del Monasterio fueron decisivos en la maduración de una nueva conciencia reflexiva hacia el monumento que acabó derivando, como hemos visto, en una redundante carga emocional. El Monasterio fue conceptuado cada vez con mayor reverencia como el símbolo de la afirmación catalanista en el pasado y, al mismo tiempo, la estimación y estudio creciente de la arquitectura medieval potenció la idea de la devolución del edificio a sus formas originales. Una destacada participación como impulsor de las obras de restauración tuvo el Obispo de Vic Josep Morgades i Gili, activa y culta personalidad del clero catalán y fundador del Museo Episcopal de Vic, que obtuvo la cesión de las ruinas a la Diócesis en el año 1885. Las obras se realizaron también en buena parte mediante la suscripción popular, como ocurrió en otros casos de obras de terminación o consolidación de monumentos especialmente emblemáticos para la memoria de la colectividad.

La formación de los proyectos de reconstrucción corrió a cargo de los arquitectos Martín Sureda y Elías Rogent; Rogent mantuvo un importante contacto con el edificio y fue el artífice material de la reconstrucción, primero en el año 1865 cuando recibe el encargo de la Academia Provincial de Bellas Artes de abordar la restauración del edificio, trazando un primer proyecto en colaboración con Augusto Font y Carreras y Francisco de Paula del Villar, pues por entonces Rogent ya era conceptuado como un reputado medievalista y estudioso de los desarrollos de la arquitectura medieval en Cataluña ${ }^{26}$. Con posterioridad, a partir del año 1885 , Elías

${ }_{26}$ De este primer proyecto de Rogent existen los planos, que, si bien elogiados por la Academia, no pudieron ser ejecutados por razones presupuestarias; noticias sobre este encargo académico nos las proporciona Augusto Font i Carreras: «Por el año 1865, ocupóse la Academia del estado de abandono en el que se encontraba esta rica joya de Cataluña y eligió a los académicos señores Rogent y Villar para que estudiando su estado y sus condiciones emitieran dictamen. Evacuado su cometido, Rogent en su parte gráfica y Villar en su informe, fue éste emitido a la de San Fernando, mereciendo de aquélla los más honrosos plácemes para su autor e instándole a que desarrollase el proyecto de restauración. Mas como quiera que Rogent tenía algunos trabajos hechos, esta Academia le confirmó el aludido proyecto, a pesar de la recomendación hecha por la de San Fernando". A. Fonti I CaRRERAs. Elogio del Arquitecto y Académico D. Elias Rogent i Amat leido en la sesión que se celebró el día 30 de diciembre de 1897. Barcelona, 1897. p.19. Elías Rogent había publicado en el año 1857 un famoso ensayo sobre esta temática que se puede considerar una proclama medievalista. E. Rogent. Arquitectura medieval en Cataluña publicado en el Acta de la sesión pública celebrada por la Academia de Bellas Artes de la provincia de Barcelona el día 11 de octubre de 1857 bajo la presidencia del IItre. Sr. D. Agustín de Torres 
Rogent reinició las obras de restauración por encargo del Obispo Morgades ${ }^{27}$. Sin embargo, entre esas dos fechas media el proyecto de restauración formado por el arquitecto Martín Sureda en el año 1880, donde se encuentran ya planteados la totalidad de los trabajos de reconstrucción que, tras realizarse de modo parcial, retomaría Rogent a partir del año 1885. Este proyecto de Sureda constituye un documento fundamental para adentrarse en la restauración del Monasterio de Santa María de Ripoll ${ }^{28}$. El concepto general de la restauración aparece expresado en la planta general del Monasterio trazada por Martín Sureda (fig. 3); varios aspectos de la organización compositiva aparecen en esta planta que refleja la concepción global de las fábricas y su restitución regulada: los ábsides, disposiciones privilegiadas en la interpretación del románico al expresar rotundamente los volúmenes interiores, aparecen totalmente despejados; el rectángulo de las naves de la Iglesia del abad Oliba, abierto en los pies por el atrio de entrada y rematado en el crucero saliente, presenta la división en tres naves, producto, como hemos dicho, de la restauración iniciada 1826; el claustro es regulado y cerrado en sus cuatro crujías, señalándose la arruinada en el lado septentrional, y el segundo patio, como espacio cercado y terraplenado con escombros. Compartiendo el muro exterior de la crujía occidental del claustro, se disponen las antiguas dependencias monásticas destinadas en la época de la restauración

Valderrama, Gobernador civil de la misma provincia para la distribución de premios a los alumnos de la escuela que los obtuvieron en los certámenes de fin de curso. Barcelona, 1857. pp. 9-20.

27 Estos dos proyectos, distantes entre sí el prolongado intervalo temporal de veinte años, testimonian la maduración de las concepciones del arquitecto, llevándole a replantear, como veremos, importantes aspectos propuestos en su primer proyecto de restauración, producto de la transformación de las concepciones y conocimientos arqueológicos del arquitecto catalán. Al término de la reconstrucción, Elías Rogent elaboró una detallada memoria de los trabajos ejecutados: E. ROGENT. Santa María de Ripoll. Informe sobre las obras realizadas en la basílica y las fuentes de la restauración. Barcelona, 1887. Además de los referidos problemas presupuestarios, posiblemente, como ocurrió en otros casos, la falta de aplicación del primer proyecto de Rogent del año 1865 - del que por otra parte no existe constancia en los archivos ministeriales - se debería al estallido tres años después de la Revolución de 1868 que motivó una suspensión estatal de los trabajos de restauración hasta clarificarse la situación administrativa de los mismos; en 1880 la restauración fue encargada a Martín Sureda como Arquitecto del Estado y a partir de 1885, al obtener la cesión de las ruinas la Diócesis, las obras de reconstrucción fueron encomendadas, como decimos, a Elias Rogent, dependencia administrativa que explica que los planos de Rogent no se encuentren en los archivos estatales.

${ }_{29}$ M. SUREDA. Proyecto de varias obras de urgente reparación y en parte de restauración del edificio, ex-Iglesia y claustros de Santa María de Ripoll. Gerona, 24 de febrero de 1880. A.G.A. (E. y C.), C. 8.045, Lg. 8.836, Exp. n.ำ 1. Martín Sureda, arquitecto con una destacada participación en la evolución arquitectónica y urbanística de en la provincia de Gerona desde su cargo oficial como Arquitecto provincial, se ocupó de la restauración del Monasterio de Santa María de Ripoll por encargo de la Comisión Provincial de Monumentos. 
a escuelas públicas y a dependencias del Ayuntamiento. El edificio se tratará de aislar eliminando la fábrica adosada a los pies del edificio, que surgía taponando parcialmente el pórtico, perteneciente a los herederos de José Graells. Todo este conjunto de construcciones subalternas desapareció para el realce de la estructura monumental del Monasterio, afirmando Sureda la necesidad de proceder al desescombro interior y aislamiento del edificio ${ }^{29}$ :

\footnotetext{
«... es necesario que se quiten las tierras y ruinas de todo el interior $y$ contigüldad exterior del edificio, y se hagan desaparecer los varios restos de construcciones modernas, superfluas, $y$ en general ruinosas, que unas adosadas y otras sobrepuestas aparecen en algunas partes, privando de ver y examinar los despiezos y disposición de importantes detalles de construcciones antiguas que convienen conocerse».
}

Las obras de reconstrucción, atendiendo al estado de ruina que presentaba el Monasterio, fueron de una cuantía considerable; de este complejo proceso de reconstrucción a nosotros nos interesará extractar tres aspectos de la intervención que enlazan con la definición estructural y decorativa de la arquitectura románica a través de los focos en los que se concentró la restauración: en primer lugar, la atención concedida a los ábsides, tanto en la recuperación de su concepto volumétrico como en la interpretación del sistema decorativo lombardo que dota de carácter a este primer románico catalán; en segundo lugar, el análisis estructural, debido sobre todo a Rogent, que se concentra en la reconstrucción de las naves posibilitando la integración de las formas constructivas de las bóvedas con los apoyos y cimborrio, recreando la sencillez estructural característica del primer románico; y, por último, la reconstrucción del claustro, esto es, de la crujía arruinada en la búsqueda de la regularidad compositiva del conjunto arquitectónico.

3.1. La recuperación volumétrica de los ábsides y la interpretación plástica de los muros con las arcuaciones lombardas.

Las primeras iniciativas adoptadas en el año de 1865 para dar comienzo a la restauración del Monasterio de Santa María de Ripoll se concentraron en la restauración del ábside; pero los trabajos debieron de quedar detenidos en este punto, para retomarse trece años más tarde, en 1879.

29 M. SUREDA. ibidem. (1880). 
Así se desprende de una detallada Memoria de la Comisión provincial de Monumentos de Gerona que relaciona los trabajos efectuados durante el segundo trimestre de ese año de $1879^{30}$. Desde estas fechas, la Comisión de Monumentos se hizo cargo del control de los trabajos de restauración del edificio. La Memoria ofrece un patético y detallado cuadro del estado de ruina del Monasterio y claustros.

Sin entrar en excesivos detalles descriptivos, desde el primer momento se nota la valorización de la parte oriental de la Iglesia, «notabilísima y tal vez única por su original arquitectura», como decía el informe. La memoria cifra como primer objetivo de la restauración la recuperación del ábside de la Iglesia, principal resultado de esta primera campaña: «Todas estas necesarias reparaciones han dado por resultado indirecto la completa reaparición del grandioso y bellísimo ábside del siglo $\mathrm{Xl}$, admiración del inteligente y gran adorno para la población» ${ }^{31}$. La recuperación volumétrica de los ábsides románicos fue una de las preocupaciones comunes en los proyectos de restauración del siglo XIX. Eugène Viollet-le-Duc en su restauración de la abacial de Saint-Sernin de Toulouse concentró su atención en recuperar la regularidad del ábside de la Iglesia. El íntimo acuerdo entre las masas exteriores y los volúmenes interiores se manifiesta con especial claridad en la zona absidial de la arquitectura románica. En Santa María de Ripoll, lo mismo que en los procesos de restauración de la Basílica de San Vicente de Ávila o la Iglesia de San Martín de Frómista, se concedió una especial importancia a la regularización armónica de los volúmenes de los ábsides. El testero oriental de Santa María de Ripoll fue despejado en su sección central que se encontraba "destrozada y aun ruinosa con motivo de la moderna construcción del camarín que se había levantado a manera de pantalla frente de dicha sección s ${ }^{32}$. La primera operación consistió, pues, en despejar el ábside central, trabajo que además implicó la desaparición de muros en la parte superior del crucero:

"Como quiera que las modernas paredes levantadas con suma irregularidad encima y entorno del Crucero impedian el desagüe de las aguas pluviales y afeaban de un modo altamente ridiculo el orden románico del Templo,

\footnotetext{
30 Memoria detallada de los trabajos que por disposición de la M.l. Comisión Provincial de Monumentos se han verificado en los claustros y en la Iglesia del Monasterio de Santa María de esta Villa desde el 31 de Marzo al 30 de junio de 1879. s/d. Firmado, José Ma Pellicer y Pagés. (Delegado de la Comisión provincial de Monumentos). A.G.A. (E. y C.), C. 8.045, Lg. 8.836.

${ }_{31}$ ibidem. §7.

32 ibidem. $\$ 4^{\circ}$. Estas estancias adosadas a los ábsides y que fueron demolidas pueden comprobarse en la planta trazada por Sureda.
} 
se han hecho desaparecer en toda su extensión que es de noventa y dos metros lineales, por tres de alto y un metro veinte centímetros de grueso".

Definidos los contornos volumétricos, se restauraron después la cornisa y los arcos ciegos de adorno, es decir, se producía la recuperación de los elementos plásticos distintivos de este primer románico, donde, ante la desnudez ornamental, la articulación plástica mural adquiere un fuerte carácter con el empleo de arcadas lombardas de arcos ciegos y lesenas aplicadas en esta zona absidial con seguridad y sobriedad, sin cubrir todo el paramento disponible ${ }^{33}$ :

"Para el debido complemento de la misma parte se ha procedido a la restauración del cornisamiento antiguo en una longitud de ochenta y seis metros lineales por cuarenta centímetros de alto y cincuenta centímetros de tizón; además se ha restaurado los arquillos de adorno en veinte y dos metros de círculo por un metro ochenta centímetros de altura, sesenta centímetros de vuelo y un metro ochenta centímetros de tizón».

La recuperación de esta característica articulación de los ábsides de Ripoll muestra el interés y comprensión artística del primer románico lombardo, con la preocupación por potenciar la visión del edificio desde fuera. Se revela la intención de integrar en la misma lógica los elementos puramente constructivos con los propiamente plásticos que refuerzan y vigorizan el concepto constructivo de una manera austera y parca. La recuperación de este sistema de articulación mural no presentó excesivos problemas al tratarse de una fórmula simple y de fácil aplicación a cualquier tipo de composición arquitectónica. Se restauraba también otro elemento decorativo característico como es la cornisa de pequeños nichos con ventanas ciegas limitadas en la parte baja por un plano inclinado que, desde el ábside, se extienden por los muros del transepto, recuperando un ejemplo correctísimo de composición arquitectónica de una fachada no principal (figs. 6 y 7 ) $^{34}$.

La reparación de los ábsides abarcó igualmente a sus partes tectónicas, con la eliminación de las arborizaciones en muros y bóvedas; en aquéllos se taparon además las numerosas grietas y fracturas en una superficie de

33 ibídem. §5. En el primer proyecto de Elías Rogent, la articulación con lesenas del ábside principal sólo recorre la mitad superior de éste (fig.6), extendiéndose las lesenas hasta la base del ábside en el plano de la zona absidial trazado por Martín Sureda en 1880 (fig. 7), disposición plástica que retoma definitivamente Rogent en su segundo proyecto de restauración (figs. 8 y 9).

34 Esta decoración del ábside fue duramente criticada por Whitehill cuando afirma que «a partir de la restauración de la decoración original, Rogent colocó una serie de arcadas totalmente injustificada y particularmente horrible". W.M. WHITEHILL. L'Art romànic... cap. IV; nota 43, p. 25. 
mil doscientos metros cuadrados, mientras que las bóvedas recibieron lechadas de cemento en los siete ábsides y posteriormente se cubrieron con tejas las cubiertas de la fábrica ${ }^{35}$. Para despejar totalmente esta zona oriental de la Iglesia —ábside central y crucero- se tuvo que proceder a efectuar importantes movimientos de tierra; la constante deposición de tierra había provocado el enterramiento de los muros de los ábsides en cuatro metros y medio de profundidad, lo que además provocaba la progresiva corrosión de la sillería de los muros debido a la constante infiltración de agua procedente de una acequia cercana (fig. 7); tras excavar y eliminar esta enorme masa de tierra, se llevó el suelo a su nivel primitivo, se eliminaron las humedades y se recuperó la esbeltez de las proporciones de los ábsides. Al mismo tiempo se descubrieron los dos ventanales de iluminación de la cripta - la popularmente conocida como La cova de la Mare de Deu- como relata el informe de 1879 (figs. 8 y 9$)^{36}$ :

"Las excavaciones han dado también otro resultado que es el descubrimiento de dos ventanales en dicha sección central y de una cripta construida debajo del presbiterio de la Iglesia que recibe la luz de los citados ventanales, siendo muy patente que dicha cripta es el punto del Templo denominado confesio o martyrium que habia en las Iglesias del estilo de la de Ripoll?.

3.2. La recreación de la solución estructural del primer románico catalán: la articulación de la bóveda de cañón continuo y apoyos en las naves de Ripoll.

Martín Sureda presentó un proyecto de restauración con una memoria muy concisa, sin apenas disquisiciones cronológicas o consideraciones sobre el estilo y de escaso interés en materia doctrinal: resulta un tanto sorprendente cómo Martín Sureda, aunque parte de un exiguo presupuesto, planifica la totalidad de la restauración del edificio, con un programa considerable de reconstrucciones, y sin apenas justificar cada una de las operaciones previstas. La planimetría aportada por Sureda tiene, sin embargo, un notable interés, comprendiendo diez hojas de planos que abarcan la totalidad del edificio. De este modo, el proyecto de Martín Sureda del año 1880 fue importante para el futuro del edificio.

La depuración formal de la Iglesia y claustros, la recuperación del estado original del conjunto y las reconstrucciones en estilo para ello ne- 
cesarias, son propuestas por el arquitecto como base programática del plan general e integral de restauración desde las primeras líneas del proyecto ${ }^{37}$ :

«las principales partes del monumental edificio que nos ocupa que por su reconocido mérito histórico y artístico se consideran dignas de conservarse, repararse, $y$ en lo necesario reedificarse, se limitan a cuanto se ofrezca para restaurar y mejorar las condiciones de todo lo concerniente a los claustros y a reparar y en lo posible restablecer la Iglesia y sus accesorios, al estado en que parece se hallaba en los siglos xI y XII".

Los escasos fondos consignados, procedentes del Estado y de donaciones de particulares, se habían empleado, como hemos visto, en la parte oriental de la Iglesia y en pequeñas reparaciones en el claustro, pero, como apuntaba Sureda, «han quedado muchas extensiones de edificio amenazando inminente ruina, hallándose entre ellas los grandes arcos y bóvedas de sobre el lado Oeste del crucero» ${ }^{38}$. Las pérdidas en la estructura constructiva del edificio románico afectaban a sus componentes estructurales fundamentales: las bóvedas del crucero y los arcos de comunicación con las naves se encontraban arruinados, lo mismo que el tramo central del crucero y la nave central. Algunas reparaciones se habian efectuado en los arcos y bóvedas de la parte oriental del crucero, en relación con la restauración del ábside, y la recomposición de "considerables superficies de paramentos de sillarejos».

Las obras proyectadas en el interior de la Iglesia comprendieron una importante cantidad de "reparaciones y reedificaciones», terminando la reparación de los ábsides y brazos testeros del crucero, con la reposición de sillarejos, y la reedificación de los arcos y bóvedas y reparación de las vertientes de las cubiertas. La preferencia otorgada por Sureda al crucero y ábside central de la Iglesia, juntc con la reedificación del claustro, presidió el orden de ejecución de los trabajos de restauración. El principio general mantenido por Sureda reposaba en una afirmación radical de la unidad de estilo, es decir, "verificando todo conforme se demuestra en los dibujos del proyecto, formado con sujeción e imitando en lo posible las partes antiguas que subsisten, a fin de restablecer las cosas al estado que la Comisión se propone, o sea aproximadamente al que parece se hallaban en el siglo $\mathrm{XI}{ }^{39}$.

\footnotetext{
M. SUREDA. (1880). $\S 1^{\circ}$.

ibídem. $2^{\circ}$.

ibidem. $2^{\mathrm{a}}$ parte, $\S^{\circ}$.
} 
Ante la parquedad interpretativa del proyecto de Sureda, el alcance de la restauración proyectada, y que acabaría consumándose años después, los planos trazados por el arquitecto ofrecen una información suplementaria. El corte transversal de la nave (interior) muestra la parte exterior occidental del crucero, con la restauración de las arquerías ciegas por este lado que continua la recuperación de este motivo lombardo que aparece en el costado opuesto del crucero (fig. 11). Un interesante corte longitudinal del transepto permite comprobar la ruina del tramo central del crucero que reedificará posteriormente Elías Rogent levantando la torre cimborrio (fig. 12). Los cuatro cortes longitudinales de la Iglesia van presentando el edificio en una síntesis de la persistencia las bóvedas góticas y la restitución románica: el corte longitudinal de la nave principal muestra, como dijimos, el testimonio de la desaparición de la antigua bóveda de cañón y su sustitución en el siglo xv por la gótica, que a su vez se había arruinado como consecuencia de la devastación del año 1835 (fig. 14); el segundo corte longitudinal reproduce las antiguas construcciones que, aunque prácticamente arruinadas, se deducian en interpretación de Sureda, como «la particular combinación y disposición decorativa de vanos y macizos reales y fingidos, de la especie de galería corrida y del antiguo remate de piedra labrada en forma de escocia y alero" (fig. 17); otro corte longitudinal de la nave central hasta el ábside por el lado opuesto al anterior representa la línea de arruinamiento de la nave y la reconstrucción dibujada de la serie de arcuaciones (fig. 18). Son estos planos representaciones longitudinales del edificio de carácter más esquemático que la sección longitudinal (fig. 15) y el alzado de la fachada lateral (fig. 16) que había dejado preparados Elías Rogent en 1865.

La reconstrucción de la Iglesia afectaba de manera especial, por tanto, a las naves que, finalmente, hubo de reconstruir Elías Rogent a partir de 1886 mediante los tres tipos de intervenciones previstas y planteadas por el arquitecto: «Primero, reconstrucción de muros sujetos a formas subsiguientes, siguiendo modelos conocidos, para continuarlas y rehacerlas; segundo, obras que, contando su pasada existencia por datos fehacientes - por analogías constructivas han desaparecido siendo necesario proyectarlas inspirándose en sus similares de los siglos respectivos; tercero, trabajos artístico monumentales que, aún cuando hayan sufrido desperfectos y modificaciones, sólo necesitan reparos que las protejan" ${ }^{40}$; lógicamente, era el segundo de estos apartados el que planteaba cuestiones de difícil resolución, que sólo podían ser afrontados con un conocimiento pormeno-

40 E. ROGent. Informe... (1887). 
rizado del estilo ${ }^{41}$. El problema de la bóveda románica denota una total comprensión estructural del edificio por Rogent: desaparecido el cañón continuo, se produce una deducción en sentido inverso, es decir, desde los apoyos hasta la bóveda. Rogent parte de la recuperación arqueológica de la planta original del edificio a partir del hallazgo de fragmentos de los fundamentos de las arcadas, de las basas y los capiteles entre las ruinas que corroboraban la descripción del Padre Villanueva que remitía a una división en cinco naves (fig. 4) ${ }^{42}$. Analizados estos elementos dispersos de modo separado, Rogent los reúne en una obra que, conforme a la austeridad decorativa de primer románico, expresa el resultado mecánico de la obra de un modo evidente. Rogent se enfrentaba con la reproducción del sistema de bóvedas románico que, desde su período germinal, había alcanzado en Ripoll un momento culminante con la construcción abovedada de un edificio de cinco naves: el método era el primitivo, es decir, una bóveda de cañón seguida en la nave central sostenida mediante toscos pilares rectangulares que, como los arcos que soportan, están severamente desprovistos de ornamentación e iluminada la nave central mediante seis ventanas abiertas sobre los pilares; las naves laterales las cubrió Rogent con bóvedas de semicirculares y las interiores por bóvedas de cuarto de círculo - según el esquema de la nave y bóvedas claustrales de Sant Llorenç de Munt- separando las colaterales por medio de una arcada en que alternan las columnas y los pilares rectangulares. A esta restauración de las naves, Whitehill objeta el carácter discutible de la forma rebajada de la bóveda de cañón central y la heterodoxia de las ventanas que iluminan la nave, objeción esta última compartida por Puig i Cadafalch ${ }^{43}$. Más dis-

41 "El segundo grupo comprende: los sustentantes y arquerías de las dobles naves laterales, incluyendo sus bóvedas respectivas, el cimborrio, ..., los campanarios ... la parte escultural y la policromía, los siete altares absidiales, los pavimentos, la cerrajería y la carpintería de taller y los demás accesorio necesarios a la celebración del culto. Ahora bien: ¿los distintos problemas que entrañan las obras últimas podemos resolverlos por los procedimientos ordinarios?. De ningún modo; esto significaria aplicar criterio subjetivo, cuando lo que deseamos... es conocer a fondo los ideales y las prácticas del siglo Xi". ibidem. (1887).

42 E. Rogent. Santa Maria de Ripoll. Informe... pp.31-32.

43 W.M. WhitehilL. L'Art romànic a Catalunya... p. 23 y J. Pulg I Cadafalch. L'Architectura romànica a Catalunya... vol.ll; p. 161. Esta resolución definitiva que plantea Rogent del problema de la reconstrucción de las naves muestra importantes diferencias respecto a su primer proyecto de restauración: en 1865, Rogent presentaba la cuatro naves cubiertas con bóvedas de cañón (fig. 15), mientras que en 1886 opta finalmente por cubrir las naves exteriores con bóveda de cuarto de cañón, dentro de una comprensión más profunda del «estilo» vinculada a posicionamientos plenamente violletianos y constructivistas en cuanto las bóvedas de cuarto de cañón debían poder contrarrestar de modo lógico el empuje ejercido por la nave central; otro elemento importante que transforma Rogent se refiere a los apoyos de las naves: en la primera versión planteaba columnas como elementos sustentantes de las naves laterales (fig.2), mientras que finalmente se decantó 
cutible fue la incorporación del cimborrio de planta octagonal del crucero, como sustitución del abovedamiento gótico de este tramo; parece ser que aunque el cimborrio con su cúpula sobre trompas aparece en la arquitectura catalana plenamente desarrollado en el siglo $\mathrm{xl}$-adquiriendo una versión destacada en San Jaime de Frontanyà- este elemento constructivo no debió de existir en la Iglesia de Santa María de Ripoll (o al menos en la versión propuesta por Elías Rogent); en este sentido, el autor anteriormente citado, el británico Whitehill, critica duramente no sólo ya su existencia sino sobre todo la versión ofrecida por Rogent (figs. 8 y 9) ${ }^{44}$. Otros aspectos discutibles desde el punto de vista arqueológico son la terminación en merlones de la torre campanario y la cubierta escalonada con que remató Rogent la otra torre arruinada (figs. 23 y 25 ) ${ }^{45}$.

A pesar de estas críticas - debidas a la arqueología aún balbuciente de Rogent - interesa destacar de esta reconstrucción de la Iglesia de Santa María de Ripoll por Elias Rogent la comprensión fundamental de la estructura de cañón continuo, interpretada de acuerdo con los materiales y el concepto expresivo originario recreando las formas sencillas y elementales del primer románico catalán. Esta «regeneración estructural» de Santa María de Ripoll se afirmaba dentro de la concepción violletiana del "estilo" amparada por el arquitecto catalán: es decir, estilo como «manifestación de un ideal establecido sobre un principio", estilo no sólo como figuración, sino también y sobre todo como estructura, como principio constructivo, que regula y dota de lógica interna al edificio.

por emplear soportes alternos de pilares y columnas (fig.5), de acuerdo, por lo demás, con el testimonio del Padre Villanueva.

44 "La cúpula de Rogent (...) es lamentable, especialmente por fuera. Se adueña del carácter ochocentista del edificio pero lo encara desde fuera y no desde dentro". W.M. WHITEHLL. ibidem. p. 24. José Puig i Cadafalch también cuestionó la existencia primitiva del cimborrio de Rogent. ibidem. La construcción de la cúpula del crucero venía ya planificada en la relación de trabajos de reconstrucción comprendidos en el proyecto de Martín Sureda. El primer proyecto de Rogent planteaba un cimborrio de planta cuadrada asentado directamente sobre los torales del crucero (figs. 6 y 10 ).

45 J. PUIG I CADAfalCH. ibidem. p, 161. Elías Rogent resolvía las torres en su primer proyecto de 1865 dotándolas de igual altura (fig. 24), con cuatro pisos de ventanas, cubriéndolas con un tejado a cuatro aguas, versión que, en el proyecto definitivo, fue desechada, aceptando en líneas generales el diferente estado conservación en que habian llegado cada una de las torres: la meridional con cinco pisos de ventanas, los dos superiores dobles y rematados por arcuaciones que reproducen la versión de la torre de San Miguel de Cuixá y San Martín de Canigó, y la septentrional con sólo dos pisos de ventanas y cubierta con un tejado de pronunciada pendiente; según Pere Hereu, esta torre, que contradice las reflexiones del informe de Rogent de 1887, puede interpretarse como una libre y poco feliz interpretación de la torre de San Lorenç de Munt. 


\subsection{El cerramiento del claustro a través de su reconstrucción}

El claustro del Monasterio de Santa María de Ripoll había sufrido considerables destrozos que afectaron especialmente a una de sus crujías, la oriental, que resultó completamente arruinada. El claustro monástico es más tardío que la Iglesia: la primera de las crujías que se construyó fue la inmediata a la Iglesia, perteneciente a los decenios finales del siglo XI; el resto se levantaron ya en período gótico, si bien, como ocurrió en el claustro de Elna, tratando de imitar las formas y proporciones de las crujías románicas ${ }^{46}$.

Las primeras reparaciones efectuadas en el claustro se concentraron en tres aspectos: la renovación total de la techumbre de la galería apoyada en el costado meridional del templo, el refuerzo de los tejados mediante tirantes de hierro y madera y la contención de la tendencia de las arcadas a desplomarse hacia fuera ${ }^{47}$. La restauración y cerramiento del claustro en sus cuatro crujías fue uno de los objetivos principales del proyecto de Martín Sureda; para ello se debía reconstruir por completo la galería oriental que, como dijimos, resultó completamente arruinada: varios restos dispersos de basas, capiteles y archivoltas se recogieron entre las ruinas y con ellos se acometió la recomposición de este lateral del claustro. El criterio de reconstrucción es sumamente representativo del método propio del siglo XIX: el objetivo -como en el resto de la Iglesia - es la recomposición original del claustro a partir reutilización. de los elementos decorativos y constructivos preexistentes y su integración indiferenciada con materiales y formas nuevas similares a las antiguas para lo restante. Martín Sureda planteó en su totalidad la reconstrucción de la crujía del claustro, que aparece en dos hojas de planos: en el frente que dispone los dos pisos (figs. 20 y 21) y un plano de detalles donde se exponen las diferencias estilísticas entre las arcadas de cada uno de las crujías del claustro, de la más antigua correspondiente al lado paralelo al eje de la Iglesia y la parte baja de las dos restantes, mientras que la parte superior es uniforme en los cuatro lados (fig. 22). Se trataba, en suma, de un ejemplo de reconstrucción que no planteaba excesivas dificultades debido a la regularidad del claustro que permitía la reproducción de los elementos de las crujías que permanecían en pie para levantar la arruinada.

46 Véase J. PUIG I CADAFALCH. L'Architectura romànica a Catalunya. vol.III.1. pp.329-331.

47 Comisión Provincial de Monumentos de Gerona. Memoria detallada de los trabajos... (1879). $\$ 8^{\circ}$ a $10^{\circ}$. 


\section{LA DEFINICIÓN HISTORIOGRÁFICA DEL PRIMER ROMÁNICO: EL ROMÁNICO LOMBARDO ITALIANO Y LA ESCUELA ROMÁNICA CATALANA EN LA OBRA DE JOSÉ PUIG I CADAFALCH.}

La restauración del Monasterio de Santa María de Ripoll dio comienzo efectivo en la década de 1880. Los estudios arqueológicos realizados por Martín Sureda y Elías Rogent para devolver el edificio a su estado original les hicieron manejar estructuras, elementos constructivos y decorativos propios del primer románico catalán, «leyendo las páginas de piedra escritas en lenguaje ideográfico en los flancos y las cumbres de las montañas catalanas», confesaba Rogent ${ }^{48}$. Se iniciaba así una labor arqueológica que en gran medida sería magistralmente culminada en el año 1911 con la publicación de la monumental obra L'Arquitectura romànica a Catalunya redactada por José Puig i Cadafalch, Antoni de Falguera y J. Goday y Casals ${ }^{49}$. Se ofrecía en este amplio y documentado trabajo una espaciosa visión del origen y desarrollo del arte románico en Cataluña. Esta obra asimilaba y superaba los estudios monográficos anteriores y los incluía dentro de una estructuración historiográfica que se apoyaba en las más recientes investigaciones arqueológicas europeas, especialmente francesas ${ }^{50}$. El rigor científico, la rigurosa descripción documental, el de-

48 Debemos subrayar el carácter pionero de los trabajos de restauración e investigación arqueológica desarrollados por Elías Rogent y Martín Sureda. En 1865, cuando Rogent elabora los planos de su primer proyecto, eran escasísimas las intervenciones de restauración ejecutadas sobre el patrimonio monumental medieval y, del mismo modo, los estudios arqueológicos sobre los que apoyarse eran sumamente exiguos. En la década de 1880 se produjo un importante despegue de la restauración monumental en España, paralelamente a una profunda renovación historiográfica en el campo de la arqueología medieval que supuso, en líneas generales, la plena aceptación del método racionalista violletiano (Véase, I. GONZÁLEZ-VARAS IBÁÑEZ. Restauración monumental en España en el siglo xIx. Valladolid, 1996). El avance de las investigaciones arqueológicas en el ventenio que separa los dos proyectos de Elías Rogent para el Monasterio de Ripoll era señalado por el propio Arquitecto: "Al trazar en 1865 el proyecto primitivo, conocía poco los principios de nuestro arte regional y faltaban obras técnicas que los explicasen. Para salvar las vallas que encontraba tomé por guías a Caveda, Battisier, Daniel Ramée, Tomás Hope, De Caumont, los Monumentos Arquitectónicos de España, el Diccionario de Viollet-le-Duc, los Monumentos Antiguos y modernos de Gailhabaud y la arquitectura del $\mathrm{V}$ al XVill siglo del mismo autor». ibídem. (1887).

${ }_{49}$ J. Puig I CAdafalch, A. DE Falguera y J. Goday I Casals. L'Arquitectura romànica a Catalunya. Barcelona, 1911. (edic.facs. Barceiona, 1983 - 2" edic.-). "L'Arquitectura Romànica fins les darreries del segle XI". vol.II; la obra fue publicada por el Institut d'Estudis Catalans tras recibir el premio del concurso Martorell en su convocatoria del año 1907. Sobre el Monasterio de Santa Maria de Ripoll, véase vol. Il; llibre II; cap. VII; pp. 153-162.

50 Desde una historia de la arquitectura concebida como historia de los "modelos", Puig i Cadafalch protagoniza en sus investigaciones un giro importantísimo en la historiografía arquitectónica española al apoyarse en la metodología abierta por los "arqueólogos", más atentos éstos a la especificidad de cada fábrica, en abierta contienda con los modelos deductivos violletianos de 
tallado análisis estructural y artístico de los edificios y la prolija exposición de los medios sociales, económicos y espirituales para su realización hacen de la obra de Puig i Cadafalch un punto de referencia constante para el estudio de la historia del primer románico catalán ${ }^{51}$. Pero esta severa urdimbre erudita y científica tiene una finalidad claramente entroncada con lo que dijimos en el primer epígrafe de este escrito, es decir, la intencionalidad de demostrar por la ilación de datos históricos cómo al período de gestación de la unidad nacionalista catalana le correspondía una misma unidad artística, aún participando de las corrientes internacionales. Las conclusivas palabras de Puig i Cadafalch son sumamente reveladoras de este sentido orientado de la Historia de la arquitectura del primer románico catalán ${ }^{52}$ :

"Investigando ésta nuestra arquitectura, rústica, sencillisima, hemos pretendido hacer algo más que el catálogo de los monumentos de una demarcación administrativa y estudiar el arte de una provincia. Recogiendo pa-

implacable ( $y$ a veces forzada) lógica racionalista, según sintetizaba, culminando el siglo, el discípulo de Eugène Viollet-le-Duc, Auguste Choisy en su célebre Histoire de l'Architecture (Paris, 1899), manual acabado y plenamente sistemático de la teoría racionalista aplicada a la Historia de la arquitectura, en acusado contraste con la concepción introducida por José Puig i Cadaflach. Este cambio cardinal de orientación metodológica queda patente en los estudios citados por Puig Cadafalch como puntos de referencia: el arquitecto catalán se apoya en la reciente obra de célebres arqueólogos franceses como BRUTAILS, especialmente su más influyente trabajo, L'archéologie du moyen-âge et ses méthodes. (Paris, 1900), o sus estudios específicos sobre el primer románi$c o$, como son sus Notes sobre l'art religiós en el Rosselló (según la traducción al catalán realizada en 1901) o su monografía sobre «Le linteau de Saint-Génis-des-Fontaines». Congrés Archéologique de France. (Paris-Caen, 1907). Otros estudios del primer románico lombardo realizados por autores franceses y utilizados por Cadafalch fueron los de J. VIREY. "Les edifices religieux de l'époque romane en Saone et Loire». Congrès archéologique de France. (Paris, 1901), P. de Truchis. "L'Architecture lombarde, ses origines, son extension dans le centre et le midi de l'Europe". Congrès Archéologique de France. (Paris-Caen, 1910), Revoll. Architecture romaine du Midi de la France. (Paris, 1873) o el estudio histórico de PITON. Les Lombards en France et à Paris. (Paris, 1892). También se manejaron los ensayos italianos más difundidos sobre la arquitectura lombarda, como eran los de G. Merzario. I Maestri Comacini. Storia artistica di milleduecento anni (600-1800). (Milano, 1893) y sobre todo el de G.T. RIvoIRA. Le origini della architettura lombarda e delle sue principali derivazioni nei paesi d'oltri Alpi. (Roma, 1908). El controvertido tema de las influencias orientales fue especialmente estudiado por Cadafalch a través de las obras de VogüÉ. Syrie centrale. (Paris, 1865-1877) y P. de TruchIS. «Les influences orientales dans l'Architecture romane de Bourgone». Congrès Archéologique de France. (Paris-Caen, 1908).

51 José Puig i Cadafalch fue igualmente un destacado arquitecto restaurador de la arquitectura románica catalana; para este semblante de su actividad es fundamental el artículo de A. GonzÁlez Moreno I NAvarRo. "A proposit de Jeroni Martorell, Puig i Cadafalch i Torrés Balbás". Diputació de Barcelona. Servei del Patrimoni Arquitectònic. Monografies. Barcelona, 1993. n.․ 3; pp. 37-57.

${ }_{52}$ ibídem. p. 584; se puede constatar esta intencionalidad -la afirmación por la Historia de las raíces culturales y espirituales del pueblo catalán- como la finalidad básica de los estudios emprendidos por iniciativa o bajo el patrocinio del Institut d'Estudis Catalans. 
cientemente las obras catalanas del siglo $x \mathrm{l}$, hemos sentido como si renaciese en nuestras manos todo un período arquitectónico que imperó durante siglos en una parte de Europa y del que el nuestro era como una variante o una sub-escuela como la unidad del pueblo que la formaba; hemos visto cómo se formó entre nosotros una arquitectura que se nutría de formas antiquísimas y hacia reflorecer en las postrimerias del siglo XI los temas que se habian aplicado en el siglo $v$ en las primeras basilicas de Occidente y revivir las piedras a la manera romana; hemos podido ver, no la obra incoherente reunida por azar en una extensión geográfica, sino la obra viva, personal, construida por un pueblo, por una unidad espirituals.

La síntesis sobre origen histórico del primer románico catalán a la que llega Puig y Cadafalch —después, claro está, de efectuar un análisis en profundidad de los atributos constructivos y estilísticos de los edificioslleva a entrelazar de un modo inteligente la independencia política que se logra durante el período condal con la creación de una arquitectura que, a pesar de responder en lo esencial a unas fórmulas artísticas supranacionales, se articula en el territorio catalán con ciertos rasgos propios, como "período que presenta una gran unidad artística en Cataluña, período de la fracción feudal y de los condados que cada día son más independientes del imperio y que poco a poco se van aglomerando en torno al condado de Barcelona» ${ }^{53}$. Todo ello era producto de la romántica «unidad espiritual» a la que aludía el historiador catalán en el párrafo anteriormente citado. Cadafalch desvela los orígenes y la secuencia evolutiva que lleva al nacimiento de la arquitectura románica catalana desde mediados del siglo $\mathrm{x}$ : la procedencia italiana de este románico lombardo no es una importación literal, pues "se aclimata al país, se convierte en cosa popular, cosa nacional que nadie tiene por exótica» 54; los métodos constructivos del primer románico son de procedencia romana - avalando la continuidad local romana- que se revisten exteriormente de la característica decoración lombarda. A partir de esta influencia lombarda, la arquitectura románica adquiere unas particularidades en su desarrollo catalán que son las que permiten a Puig i Cadafalch definir la sub-escuela nacional catalana; sintetizando, estas diferencias se localizan en algunos aspectos relativos al empleo de las soluciones abovedadas que lógicamente son enfatizadas por el historiador catalán ${ }^{55}$ :

"La forma interior de nuestras iglesias ... no tiene casi semejanza con las iglesias lombardas antiguas cubiertas de madera, ni con las cubiertas con

\footnotetext{
ibidem. p. 10.

ibidem. p. 576.

ibidem. pp. 579-580.
} 
bóvedas de arista en las naves laterales y por una cubierta de madera en la nave central, ni con algunas de las formas de construcción adoptadas. La forma lombarda origina en Cataluña una estructura desconocida en Lombardía, una construcción de bóveda de piedra, siguiendo los métodos que los constructores romanos usaron en la extensión de la tierra que comienza en la Provenza y sigue por la Francia meridional hasta España, como si el templo románico catalán hubiese nacido del maridaje con las formas ravenantes de una construcción indígena, casi rural por su sencillez, construida por los mismos procedimientos, concebida con el mismo espíritu que la infraestructura de los circos y de los anfiteatros romanos (...) Resumiendo: los métodos constructivos del primer período románico son romanos locales a los que revistieron exteriormente una decoración lombarda".

La arquitectura románica catalana participa de un carácter internacional que vincula a Cataluña con el área política y cultural de Italia, la Germania, el reino de Borgoña, que comprendía las tierras del Ródano y el Saona hasta los Alpes y el mar, incluyendo Saboya y la Provenza y extendiendo su influencia hasta los Pirineos y las tierras de la Marca hispánica. Dentro de este mundo artístico uniforme se define esta "sub-escuela catalana» que abarca desde las costas de Italia hasta el País vasco siguiendo los Pirineos; pero, a su vez, Cadafalch fracciona aún más este área hasta identificar la aportación arquitectónica propiamente catalana — definida, como hemos visto, por la estructura de bóveda de cañón y ornamentación lombarda en muros - hasta determinar "la tierra de nuestra escuela románica del siglo X|», limitada por el sur con la frontera musulmana y extendiéndose por la franja pireanaica hasta el Garona y por la costa mediterránea hasta más allá de Narbona, esto es y como quería concluir Cadafalch, abarcando «casi el dominio de la lengua catalana, provincia de un reino más vasto de la gran extensión de la escuela románica» ${ }^{56}$.

La unidad de Cataluña como pueblo - una vez definida su singularidad como poseedora de una tradición artística y cultural propia- quedaba afirmada desde este período de génesis: «tierra montañosa, pueblo rústico, va entrando poco a poco en la civilización que va creando ella misma, con sus propios medios" ${ }^{57}$. Se trataba de recuperar para la Historia lo que había reactivado emocionalmente la Cataluña del siglo XIX, esto es, la búsqueda en esta tosca arquitectura de la esencialidad creadora del pueblo en su fluir natural y espontáneo, en su naturaleza originaria, que rehabilitaba - después de la línea de pensamiento abierta por el historicismo romántico- lo original y privativo de la cultura catalana.

\footnotetext{
56 ibidem. pp. 583-584.

57 ibidem. p. 575.
} 
Pero esta defensa de los modos de construir locales enraizada con la apología del espíritu nacional fue igualmente sentida por la historiografía italiana en su profundización sobre la arquitectura lombarda, como ha sido recientemente estudiado ${ }^{58}$. Los primeros intentos de los historiadores italianos por definir la arquitectura lombarda, como fue la obra de Giulio Cordero Dell'italiana architettura durante la dominazione longobarda (Brescia, 1829), se volcaron en la afirmación de la defensa de la autonomía del arte italiano respecto a los invasores longobardos ${ }^{59}$. Las conclusiones de Cordero, impregnadas de las aspiraciones nacionalistas de una Italia desmembrada, afirmaban el carácter italiano de esta arquitectura que, a pesar de las influencias árabes y orientales, mantiene intacta en lo sustancial su autonomía y sus raíces romanas. Posteriormente, se desarrollará una interesante labor por clarificar estilísticamente el primer románico meridional o lombardo. Existe una secuencia de estudios que recorren toda la segunda mitad del siglo XIX: Edoardo Arborio Mella ${ }^{60}$-que presenta a la arquitectura lombarda como una conjunción de influencias romanas y bizantinas-Celeste Clerecetti ${ }^{61}$ - que igualmente reivindica el carácter nacional italiano de la arquitectura lombarda- el francés Ferdinand de Dartein ${ }^{62}$-que insiste en esta perspectiva al mismo tiempo que define los rasgos constructivos de esta arquitectura- o la consagración historiográfica de los magistri comancini, depositarios de la tradición constructiva romana, por Giuseppe Merzario ${ }^{63}$. Entre estos estudios es también interesante señalar el realizado por Teresio Rivoira, en el primer decenio del siglo, pues aparece citado en numerosas ocasiones por Puig i Cadafalch y que tuvo la importancia de presentar las fuentes de la arqui-

58 Me refiero al magnífico estudio de G. GuaRIsco. Romanico, uno stile per il restauro. L'attività di tutela a Como, 1860-1915. Milano, 1992. En este libro se plantea la actividad restauradora desarrollada sobre las fábricas del primer románico lombardo considerando los procesos de restauración en íntima relación con los esfuerzos historiográficos por definir las raíces culturales y estilisticas de la arquitectura románica.

59 La obra de Giulio Cordero tuvo su origen en un concurso convocado por el Ateneo de Brescia al que concurrieron igualmente los primos Giuseppe y Defendente Sacchi y Antonio Noale. Véase G. PANAzZA. // concorso per il premio biennale dell'Ateneo di Brescia sul'Architettura Jongobarda del 1826-1829. Brescia, 1896.

60 E.A. MELLA. Elementi di architettura gotica da documenti antichi trovati in Germania. Studi leorico-pratici sulla genesi dell'architettura archi-acuta. Milano, 1857 (prima parte); Milano, 1863 (seconda parte). La actividad restauradora de Melia es estudiada, además del análisis general de Guarisco (pp. 67-69), por F. MoRgantini. Edoardo Arborio Mella restauratore (1808-1884). Milano. 1988.

61 C. CleRECETTI. Ricerche sull'Architettura Lombarda. Milano, 1869. Guarisco, (pp. 69-72).

62 F. DE DARTEIN. Étude sur l'architecture lombarde. Paris, 1865-1882. Guarisco, (pp. 72-76).

63 G. Merzario. I Maestri Comacini. Storia artistica di milleduecento anni (600-1800). Milano, 1893. Guarisco, (pp. 86-88). 
tectura lombarda en una amplia cadena evolutiva que establecía las raíces del románico lombardo en la arquitectura romana pero con aspectos decorativos procedentes de edificios ravenáticos ${ }^{64}$. Todos estos ensayos arqueológicos, que reconocen y definen una de las secuencias más singulares y propias de la arquitectura italiana, armaron de argumentos a las generaciones de arquitectos que no dudaron -apoyados por el recién creado Estado unitario- en recuperar la condición originaria de estos monumentos que expresaban el pasado legendario de los más altos ideales cívicos de autonomía e independencia de las primitivas comunidades locales. En la restauración siguieron y aplicaron fielmente el principio de la unidad de estilo dando lugar a una serie de intervenciones sumamente significativas como son los tres ejemplos paradigmáticos de las restauraciones de las basílicas de S. Abondio (1863-1935), S. Carpoforo (18641910 ) y S. Fedele (1867-1915). En torno a estos procesos de restauro comasco se formó una importante escuela de restauradores como Vincenzo Barelli, Luigi Tatti, Alfonso Garovaglio, Serafino Balestra, Luigi Perrone y Antonio Giussani ${ }^{65}$.

Una importancia similar a estos destacados ejemplos italianos de restauración de la arquitectura románico-lombarda, aunque más retrasada en su aparición, se concentró en torno al proceso de restauración del Monasterio de Santáa María de Ripoll. Al destacado papel simbólico que desempeñó el Monasterio ripollés, se sumaba su consideración como testimonio trascendental dentro de la evolución histórica de la arquitectura románica catalana. Elías Rogent fue consciente de esta destacada importancia que asumía el Monasterio de Ripoll en el panorama arquitectónico del primer románico catalán. Los primeros ensayos de la balbuciente arquitectura románica del siglo $\mathrm{x}$ alcanzan un momento de esplendor y mag-

64 G.T. RivolRA. Le origini della architettura lombarda e delle sue principali derivazioni nei paesi d'oltri Alpi. Roma, 1908. Guarisco, (pp.88-91). Teresio Rivoira trató de colmar la laguna en el proceso de periodización estilística de los siglos IV al VI que llevaba al románico lombardo de finales del siglo $X$, vacío que había quedado caracterizado por la historiografía ochocentesca como un arco temporal de exclusivo dominio artístico bizantino; Rivoira define la arquitectura que denomina "romano ravennante", como un estilo que ya no es romano pero que todavia no es comacino, estilo generador de la arquitectura lombarda, primera fase evolutiva del desaparecido arte romano que es continuado por un «stile bizantino-ravennate»; el resultado, orientado como decimos a clarificar las fuentes de la arquitectura lombarda, era la exposición de ésta como el resultado «de un compromiso del arte prelombardo con el romano-ravenante y con el bizantino-ravenantes. (G.T. RivolRA. (1908) p. 193).

65 Véase G. Guarisco. Romanico... Parte seconda, «Una storia parallela: l'attività di tutela e i restauri nella provincia comasca». cap.1, "Gli organismi per la tutela dei monumenti», (pp. 109136); cap. 2, «L'omologazione del patrimonio romanico; i restauri romantici», (pp. 137-196); y cap. 3, «l protagonisti del restauro comasco», (pp. 197-207). 
nificencia en Ripoll al finalizar el primer tercio del siglo XI. La experimentación anterior da lugar a este monumento culminante que resume los esfuerzos por abovedar las naves de los templos. Se trataba del impulso constructivo de la década del 1030 al 1040, cuando se producen igualmente las consagraciones de Cuixá (1035), y Vic (1038), en suma, «la edad de oro de nuestra arquitectura», como definió Cadafalch. En este momento quedaban fijados todos los rasgos del estilo, como brevemente los resumía el arquitecto catalán: "el plan con las más sabias complicaciones y las soluciones más simples, los ábsides triconques, el sistema de bóvedas, el transepto, el cimborrio, la composición y la decoración interior y exterior". Los elementos estructurales y decorativos característicos de este momento en que la arquitectura catalana alcanzaba su cúspide, tras más de medio siglo de sostenido tesón artístico, tratarían de ser compilados y reproducidos en la reconstrucción de Santa María de Ripoll durante los últimos decenios del siglo XIX.

\section{CONCLUSIÓN: LA ARQUITECTURA ROMÁNICA COMO SECUENCIA EN EL HISTORICISMO NEOMEDIEVALISTA}

La restauración-reconstrucción del Monasterio de Santa María de Ripoll fue punto de partida de las intervenciones en el patrimonio arquitectónico catalán ${ }^{66}$. La trayectoria arquitectónica de Elías Rogent tuvo en Ripoll un punto de reflexión fundamental: después de su aprendizaje en la Escuela de la Lonja de Barcelona, pudo recoger lo más granado de la enseñanza romántica de Antonio Zabaleta y Aníbal Álvarez y del modelo ético-artístico de los nazarenos; significativamente, Elías Rogent se graduó como arquitecto en 1851 con un proyecto de convento de monjas en estilo ojival, prueba de su compromiso medievalista ${ }^{67}$; esta opción sería potenciada por el arquitecto catalán a partir de su conocimiento directo del Rundbogenstil alemán a través de su viaje de estudios del año 1855. La evidente figuración simbólica de Santa María de Ripoll, su significado recuperado en el último tercio del siglo xix — como templo de los condes ca-

66 El otro gran proceso fue el de terminación de la Catedral de Barcelona con la construcción de su fachada y cimborrio. Véase, I. GONZÁLEZ-VARAS IBÁÑEz. Restauración monumental en España en el siglo $X I X .(1996)$.

67 F. BERTRÁN Y DE AMAT. Del origen y doctrinas de la Escuela Romántica, y de la participación que tuvieron en el adelantamiento de las Bellas artes de Barcelona los señores D. Pablo y $D$. Manuel Milá i Fontanals y D. Claudio Lorenzale. Discurso leído en la Academia de Bellas Artes de Barcelona el 12 de abril de 1891. Barcelona, 1891. pp. 63-64. 
talanes-y su sentido como punto culminante del primer románico catalán -el estilo nacional- actuaron como impulsos para la reconstrucción que tuvo en Rogent al hermeneuta de la síntesis de nacionalismo y catolicismo vinculados con el monumento medieval. Tras la fundación en 1871 de la Escuela Provincial de Arquitectura de Barcelona, Rogent ocupó la dirección desde 1871 hasta 1889, contribuyendo a la difusión de estos ideales arquitectónicos neomedievalistas, puente hacia la arquitectura modernista. Entre estos estímulos «emocionales», Elías Rogent tuvo la gran importancia de presidir la introducción de la arquitectura románica como una secuencia racional y dotada de una estética propia - que él entendía como la síntesis de las fuentes orientales y occidentales-capaz de aunar los principios constructivos y la regulación compositiva con el ejercicio imaginativo, como declaró explícitamente en un discurso pronunciado ante la Academia barcelonesa ${ }^{68}$ :

"el romanismo no sufre el yugo de la plantilla que corta el vuelo de la imaginación, y ... dentro de la unidad dogmática conserva el libre albedrio en el desenvolvimiento de la forma. El arte que tan libremente obra, el arte que tan desembarazadamente resuelve los problemas que surgen en el detalle de las obras, debió tener principios fijos que respondieran a sus necesidades».

Con esta estimación de Rogent, la arquitectura románica, como opción neomedievalista, adquiría un sólido puntal interpretativo que superaba aquellas valoraciones que lo relegaban a una posición secundaria frente al prodigio constructivo gótico ${ }^{69}$. Efectivamente, la consideración historio-

68 E. Rogent. Memoria histórico-descriptiva del santuario de San Cugat del Vallés. Barcelona, 27 de junio de 1881. Boletín de la Real Academia de Bellas Artes de San Fernando. Madrid, 1881.

69 Este relativo oscurecimiento al que quedó relegada la arquitectura románica durante el siglo $x 1 x$ frente a las grandes construcciones góticas se explicaría por dos factores principales: por una parte, por el peso de la explicación histórica de raigambre hegeliana que, desde las reputadas síntesis de Francisco Pi i Margall y José Caveda y Nava en su preocupación por buscar la trama subyacente de la historia de la arquitectura, conceptuaron al género románico-bizantino como «el emblema del poder teocrático", como una arquitectura "enteramente sacerdotal" (J. CAVEDA $r$ Nava. Ensayo histórico de los diversos géneros de arquitectura cultivados en España desde la dominación romana hasta nuestros dias. Madrid, 1848; pp. 161 y ss. y F. PI I MARgall. Recuerdos y Bellezas de España. "Cataluña”; (1843) t. II; p. 28). Es decir, un modelo ético-constructivo poco acorde con los intereses de la burguesia, aun aquélla conservadora, a pesar de que particularmente Rogent se esforzara por demostrar la plena racionalidad del románico de un modo similar al que realizó Juan de Madrazo con el gótico (para este último aspecto, véase I. GonzÁLEZ-VARAS IBÁÑEz. La Catedral de León. Historia y restauración -cap. V- (1993); en segundo lugar, y en conexión con esta valoración historiográfica, la arquitectura gótica se impuso mayoritariamente en casi todos los ámbitos porque como modelo constructivo suponia, en definitiva, el antecedente histórico de las nuevas técnicas constructivas del hierro y el hormigón, esto es, tanto por su origen histórico - conectado con la afirmación del poder burgués laico- como por sus razones cons- 
gráfica predominante en Europa respecto al estilo románico fue la de una fase de transición, un momento preparatorio o experimental, que había de llevar a las grandes catedrales góticas. El goticista Sulpiz Boisseré mantuvo esta consideración del "altdeutscher Rundbogenstil" en su estudio Denkmale der deutscher Architektur am Nieder Rhein vom VII zum XIII Jahrhundert, publicado en 1833. El completo cuadro evolutivo que presentó Eugène Viollet-le-Duc en su Dictionnaire raisonné de l'Architecture française du XI au XVlè siècle, con la demostración razonada de todos los pasos constructivos que llevaban desde la bóveda de cañón al sistema de crucería, afirmó esta consideración del románico como estilo de transición, de "aspiración metódica", como decía a finales de siglo Auguste Choisy ${ }^{70}$. Este juicio, que situaba a la arquitectura románica como una tentativa aún imperfecta en la resolución del problema constructivo del abovedamiento, fue compartido plenamente por Manuel Aníbal Álvarez, restaurador de San Martín de Frómista, que cifraba las deformaciones y desequilibrios estructurales de la Iglesia románica palentina como una consecuencia inevitable del sistema constructivo románico ${ }^{71}$. Sin embargo, en Alemania, desde muy temprano, se afrontó la consideración del Rundbogenstil como un estilo susceptible de experimentarse para las construcciones contemporáneas ${ }^{72}$. El neorrománico tuvo una fase de flo-

tructivas - que permitian su lectura en términos de técnicas y materiales contemporáneos para fundamentar la utopia del futuro- superó y relegó a una posición marginal a la arquitectura románica.

70 El esquema histórico de evolución de la arquitectura bajomedieval revelado por Eugène Viollet-le-Duc, y reforzado a finales de siglo por Auguste Choisy, consideraba al período románico como una fase previa y experimental que, a través de una secuencia evolutiva lógica y razonada, desembocaba en la arquitectura gótica; de acuerdo con la teoria racionalista, las grandes catedrales góticas eran el punto culminante del modelo teorético de evolución de la arquitectura medieval. La conocida frase de Auguste Choisy marcaba claramente las diferencias entre una y otra fase constructiva: «la una -la arquitectura románica- marca la aspiración metódica, la otra -la gótica- el resultado adquirido" (A. CHOISY. "L'Architecture romane". Histoire de l'Architecture. Paris, 1899. chap. XV; p. 140).

${ }_{71}$ "Las causas del mal estado de la Iglesia de San Martín en Frómista son varias; la principal es ei sistema de construcción empleado en la época. Todas las iglesias que hemos visto en cañón seguido se encuentran en parecidas circunstancias. El cañón central por su propio peso se abre por la clave, empuja y aumenta la propia deformación de las naves laterales, transmitiéndose el movimiento hasta sus fachadas; de aquí que obedezcan a esta causa las grietas y deformación de la nave central y lateral derecha". (M.A. Álvarez. Proyecto de restauración de la iglesia de San Martín de Frómista. Madrid, 28 de septiembre de 1895. A.G.A. (E.y C.), C. 8.208, Lg. 8.947-12).

72 Heinrich Hübsch, alumno de Weinbrenner, presenta con toda claridad esta opción en 1828 cuando se formulaba la cuestión clave - tantas veces repetida- de la arquitectura del siglo XIX: In welchem Style sollen wir bauen?. (¿En qué estilo debemos construir?. Karlsruhe, 1828). La experiencia constructiva de Hübsch como arquitecto del antiguo Land de Baden Baden demostró la posibilidad de llegar a interesantes resultados con una versión propia del Rundbogen que tomaba soluciones decorativas características del romanico lombardo: El Ministerio de Finanzas (1829), la 
recimiento igualmente en Italia entre los años de 1840 a 1860 , entrelazado con las aspiraciones de unidad nacional, y prolongándose más allá de esa fecha en convivencia con la tendencia «oficial» neorrenacentista ${ }^{73}$. Algo similar ocurrió con esa mixtura entre la restauración y la creación que mantuvo Paul Abadie en su papel de centralizador de la tendencia neorrománica en Francia ${ }^{74}$. Estos breves paralelismos dentro de la cultura neomedieval europea permiten entender la actividad pionera de Elías Rogent: con el mismo afán arqueológico y unas implicaciones ideológicas características de la Cataluña de la segunda mitad del siglo, la labor historiográfica y restauradora iniciada sobre románico catalán permitió conectar con una tradición genuina que, como demostró magistralmente Rogent, también era capaz de posibilitar ulteriores desarrollos en la arquitectura contemporánea tras sobrepasar el modelo local y recrearlo a partir del conocimiento directo del Rundbogenstil alemán. Elías Rogent recreó la combinación estructural básica de bóveda de cañón continuo con soportes, que suponía remontarse al embrión constructivo de la arquitectura románica. Se trató, en definitiva, de recrear una arquitectura arruinada más que de consolidar una ruina venerable. Al mismo tiempo -a pesar del carácter austero y ruclo de esta arquitectura - se advierte la comprensión por Rogent de esa sencillez ornamental puesta al servicio de una estructura sincera -e incluso un tanto ingenua- que convive con la armonía compositiva como el gran logro que introdujo la arquitectura románica. Se recuperaba de este modo el símbolo de la tradición artística catalana, con

Technische Hochschule (1832) en Karlsruhe y, sobre todo la Trinkhalle de Baden Baden (1840) son los ejemplos más notables de estos desarrollos del neorrománico. En la zona de Baden, el arquitecto Friedrich Eisenlohr - con la famosa estación de ferrocarril de Karlsruhe-continúan esta tendencia que recibió su sanción histórica y arquitectónica con Gottfried Semper. La región bávara fue la otra gran área de influencia del Rundbogenstil alemán, que se extiende hasta Mónaco con Friedrich von Gärtner. El neorrománico se coavierte en una opción marcadamente ecléctica, en el genuino sentido del término, que agrupa características paleocristinas, bizantinas, ravenantes y románico lombardas y hasta del primer renacimiento florentino.

${ }_{73}$ El entusiasmo de las palabras del joven Camillo Boito, discípulo de Pietro Selvatico, estimularon el revival del romanico lombardo en Italia, definiendo a la arquitectura comacina como la más alta expresión de la cultura lombarda: «Los arquitectos del porvenir se aliarán con el estilo arquitectónico de la patria renovada; harán como los artistas del Risorgimento hicieron con el arte romano, y, tomando de nuevo la cadena rota desde hace siglos, compondrán con los nuevos anillos una manera moderna, elegantemente robusta, plena de sabiduría y de ardor, rica y económica a la vez, eminentemente italiana" (C. BOITO. "La chiesa di S. Abondio-Lettere da Como". La Perseveranza; (1865). En los años posteriores a la unificación, la actividad de restauración en la arquitectura lombarda corrió pareja a las hipótesis estilísticas de los historiadores de la arquitectura en el propósito común de datar y reconocer los caracteres definitorios de la arquitectura lombarda.

74 Véase. Paul Abadie, architecte; 1812-1884. Catalogue dell'Exposition présentée du 4 no. vembre 1988 au 16 janvier 1989 au Musée national des Monuments français. Paris, 1988. 
toda la carga emocional de remontarse a los momentos germinales de un pueblo que se expresaba arquitectónicamente con una gran sinceridad constructiva.

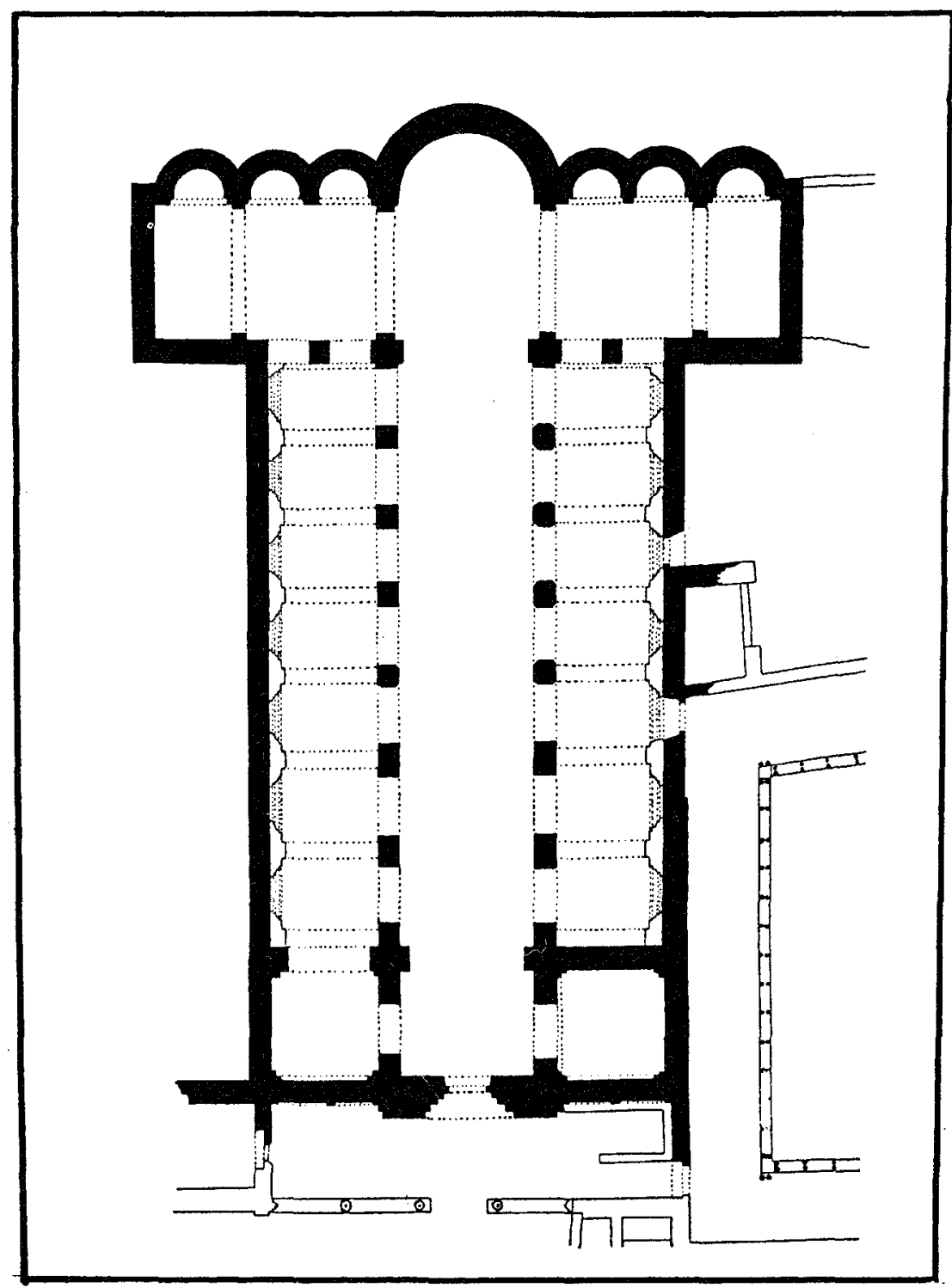

Fig. 1. Marqués de Dou. Planta de la Iglesia antes de la restauración. J. Puig i Cadafalch. L'Architectura romanica a Catalunya. Barcelona, 1907. vol.II, p.156. 


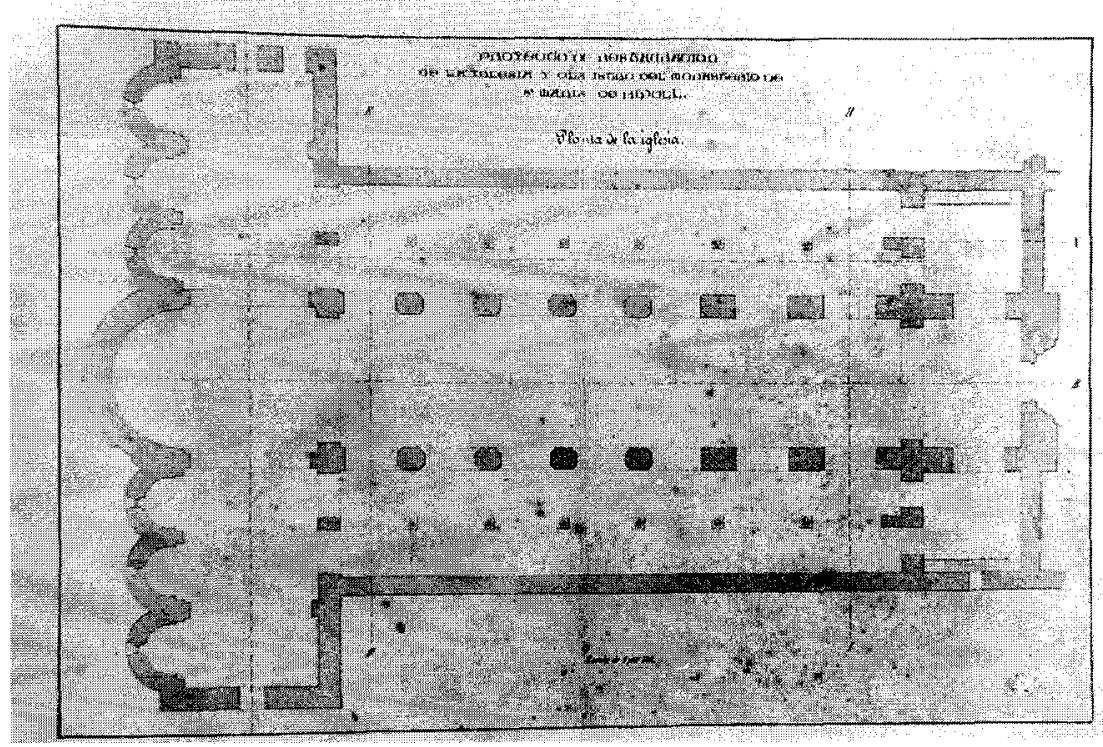

Fig. 2. Elías Rogent. Planta de la Iglesia. Primer proyecto de restauración. (1865).

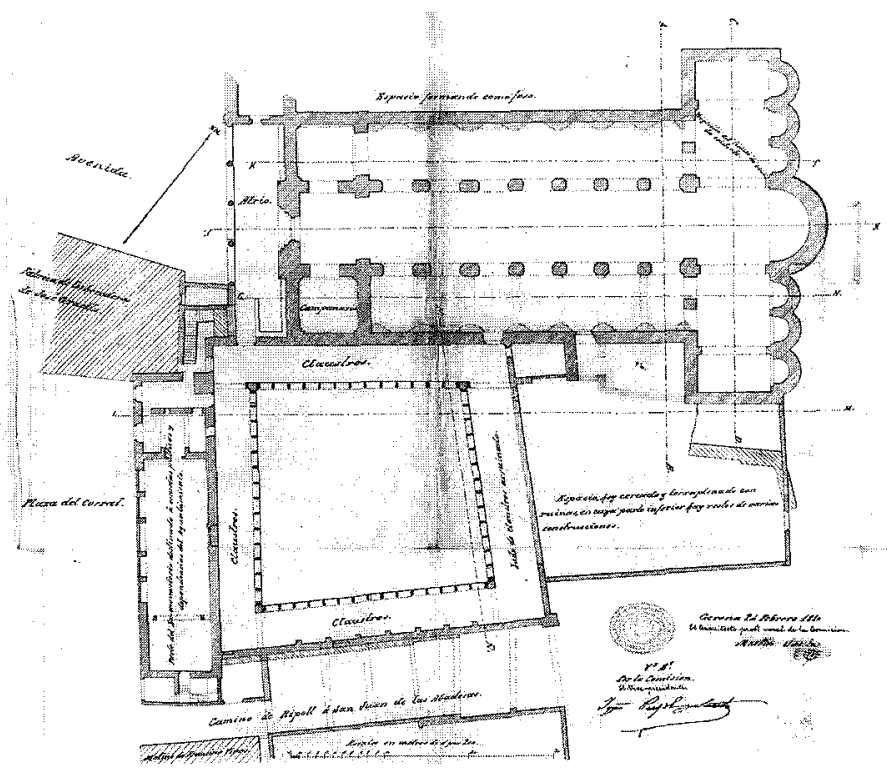

Fig. 3. Martín Sureda. Planta baja general del Monasterio de Santa María de Ripoll. Proyecto de varias obras de urgente reparación y en parte de restauración del edificio y claustros de Santa María de Ripoll. Gerona, 24 de febrero de 1880. hoja n 1. A.G.A. (E. y C.), C. 8.045 , Lg. 8.836 , Exp. $n^{\circ} 9$ 


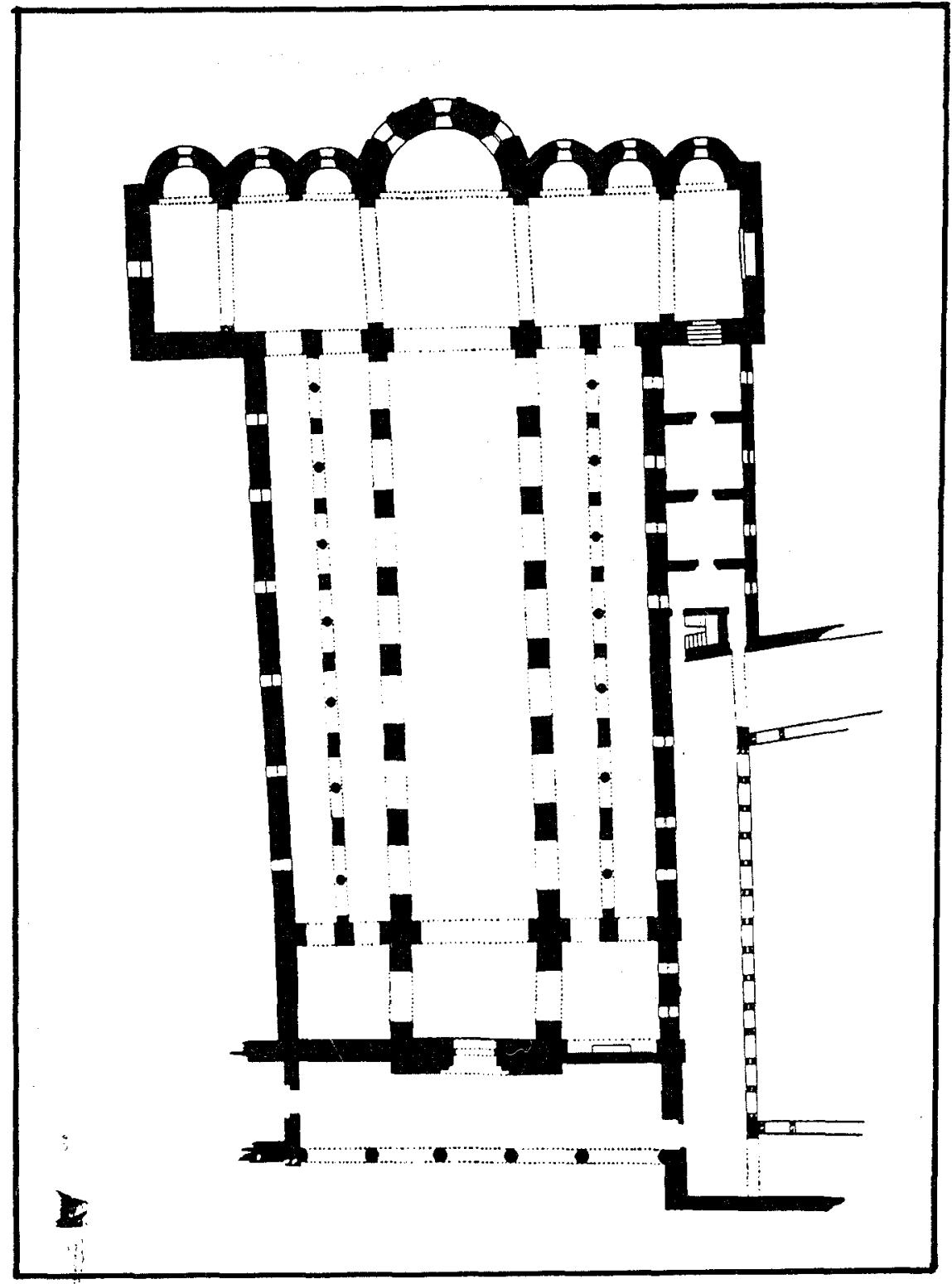

Fig. 4. Elías Rogent. Planta de la Iglesia. Segundo proyecto de restauración. (1886). 


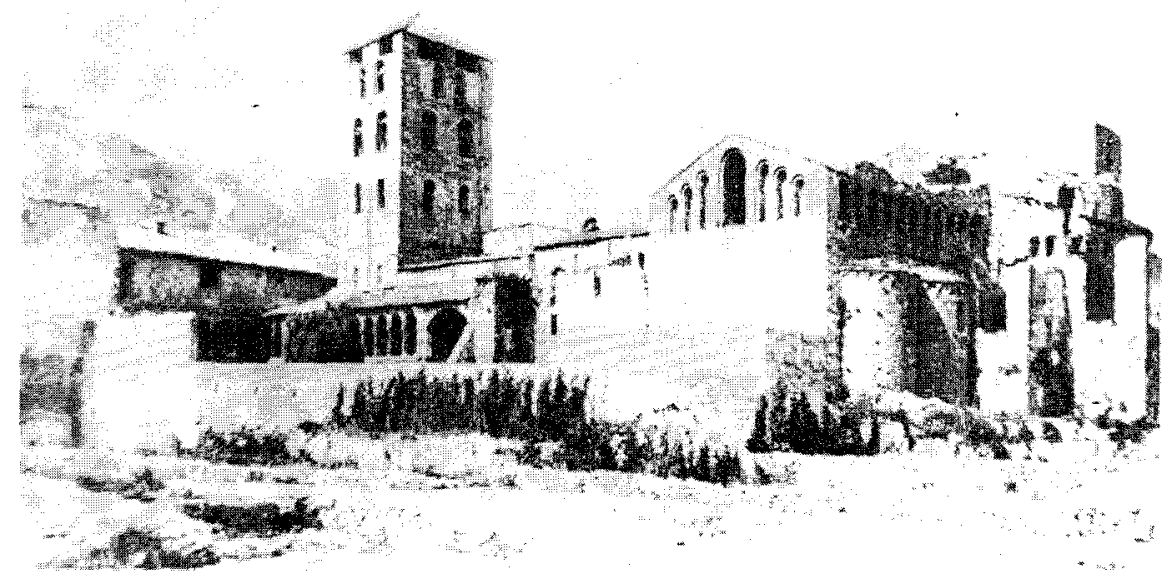

Fig. 5. Estado general del conjunto monumental de Ripoll antes de la restauración.

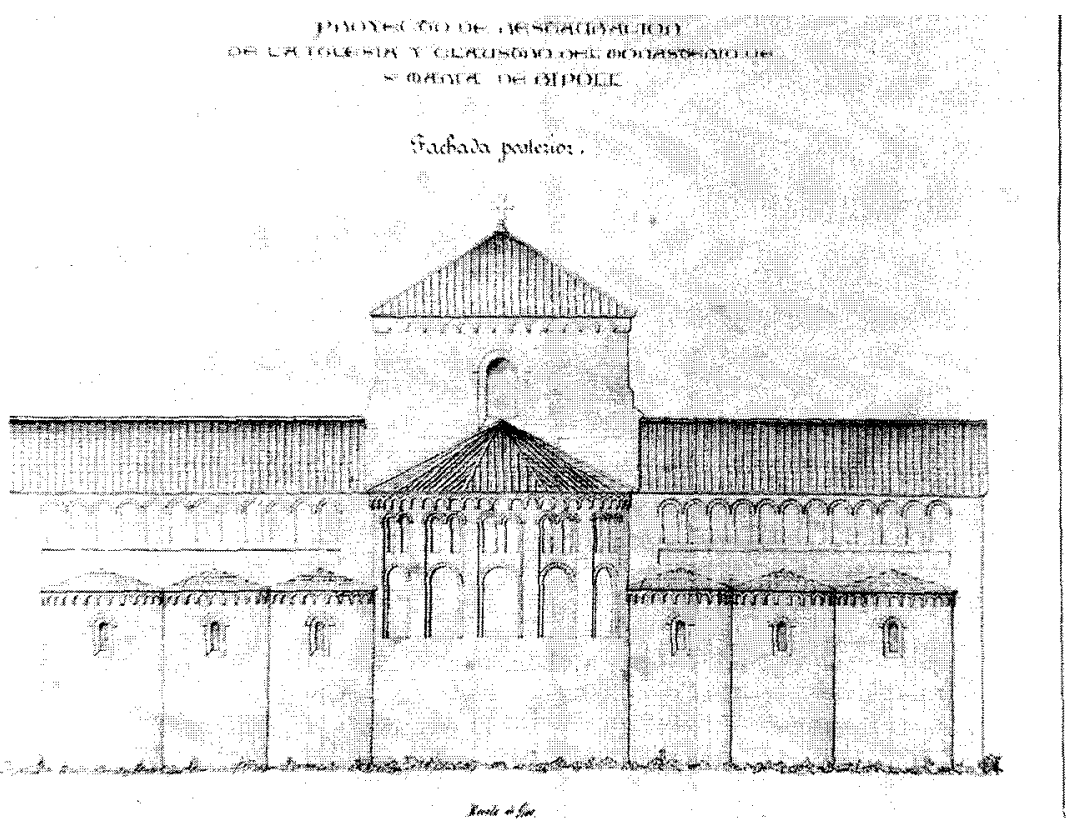

Fig. 6. Elías Rogent. Primera propuesta de restauración de la fachada oriental. (1865). 


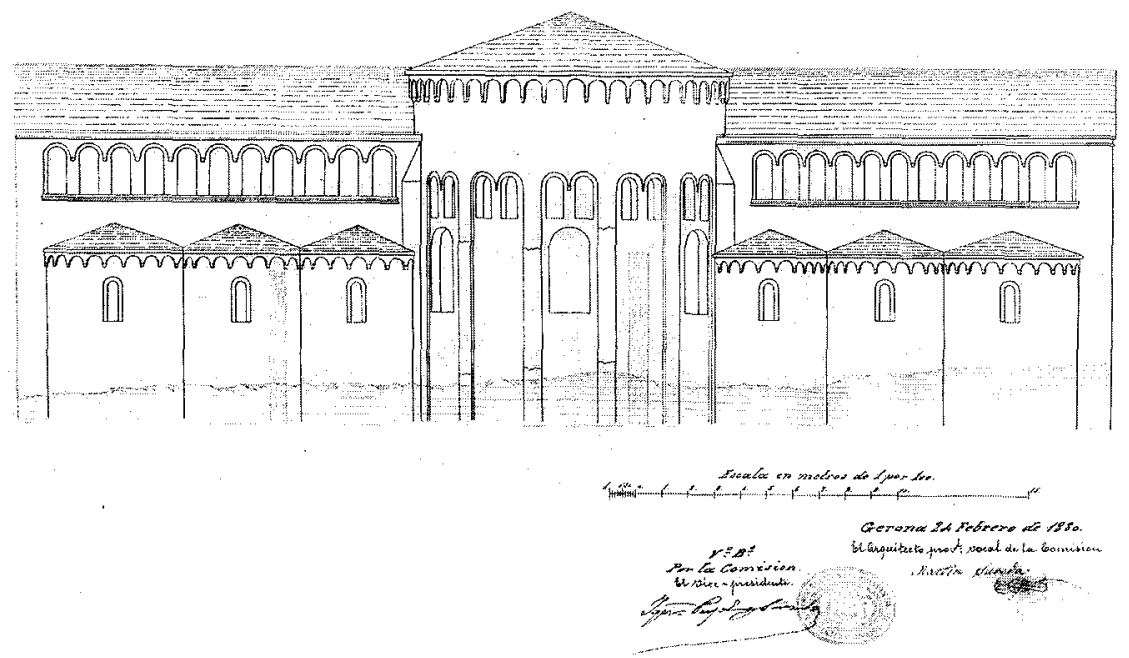

Fig. 7. Martín Sureda. Fachada oriental. Proyecto de restauración. (1880).

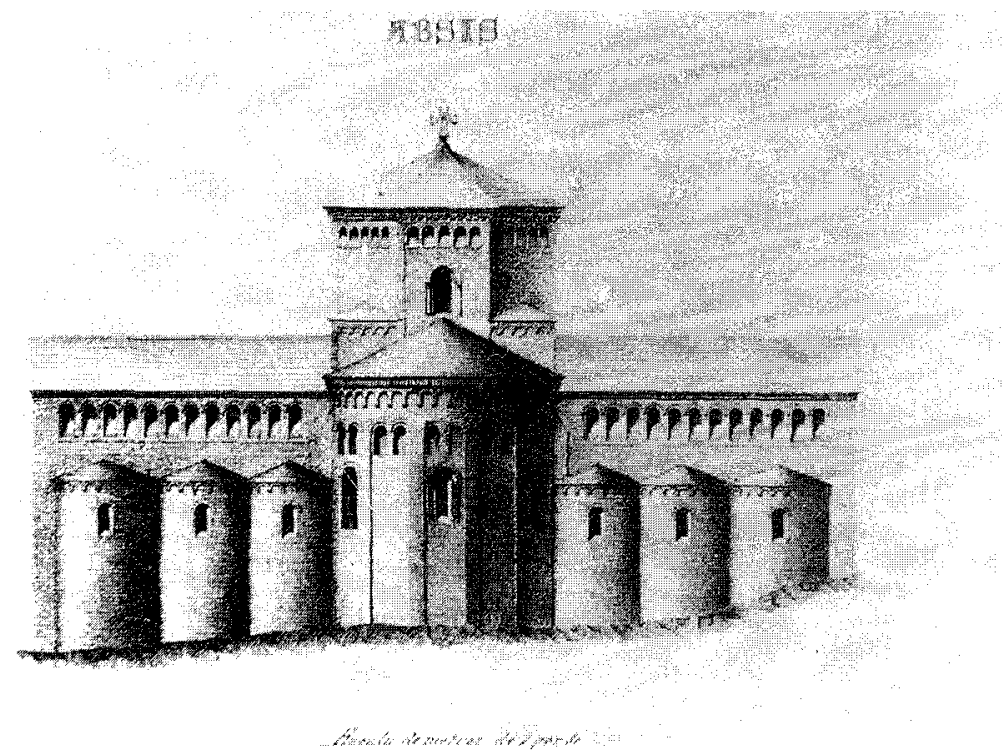

Fig. 8. Elías Rogent. Fachada oriental. Proyecto de restauración. (1886). 


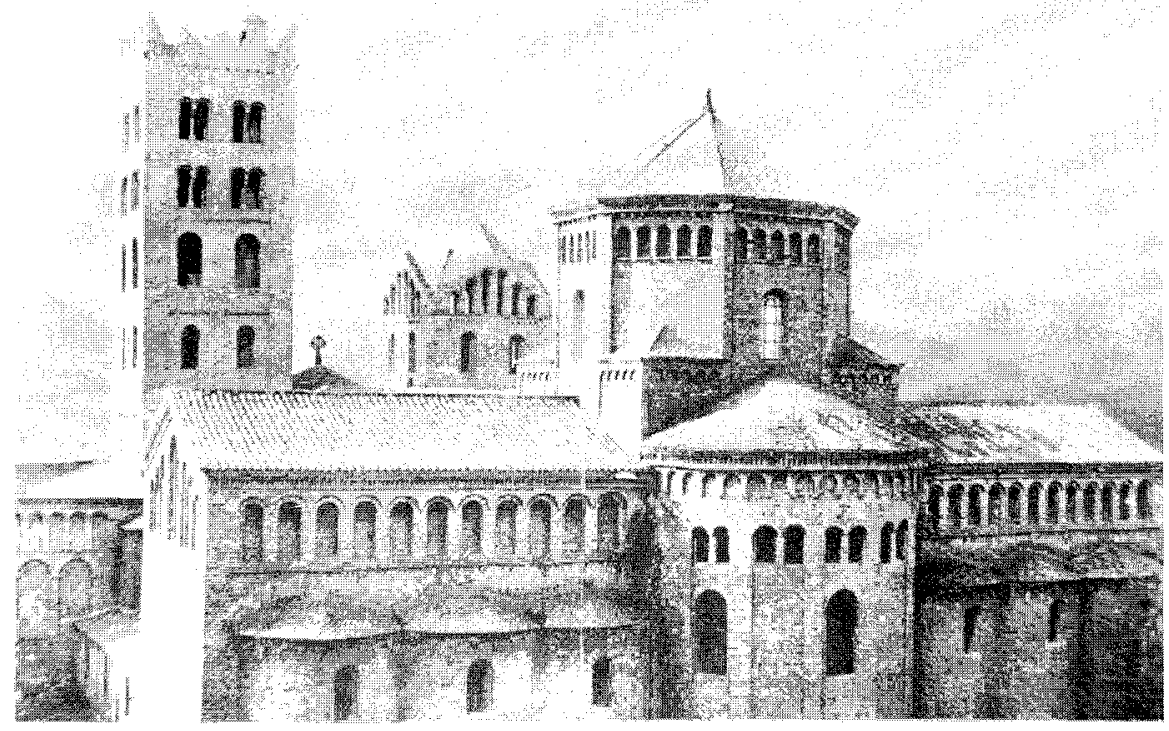

Fig. 9. Estado de la zona absidial y cimborrio después de la restauración.

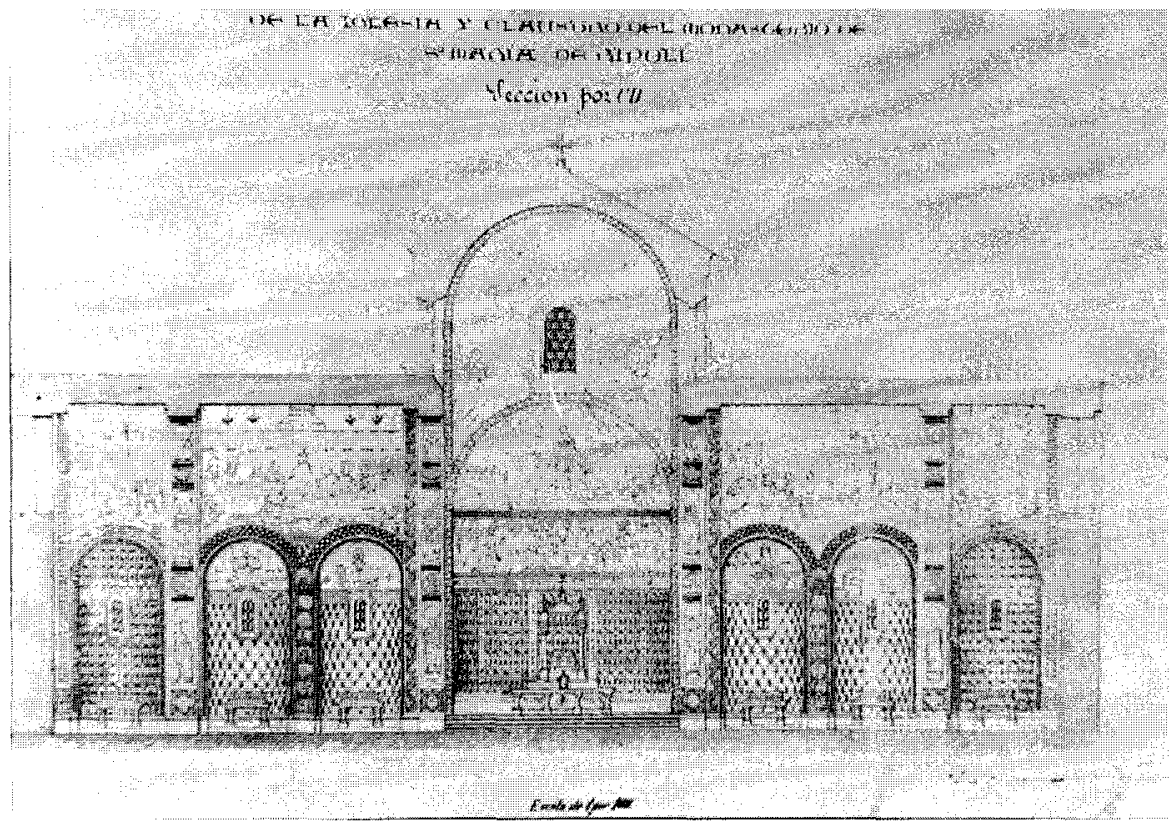

Fig. 10. Elías Rogent. Sección por el crucero. (1865). 


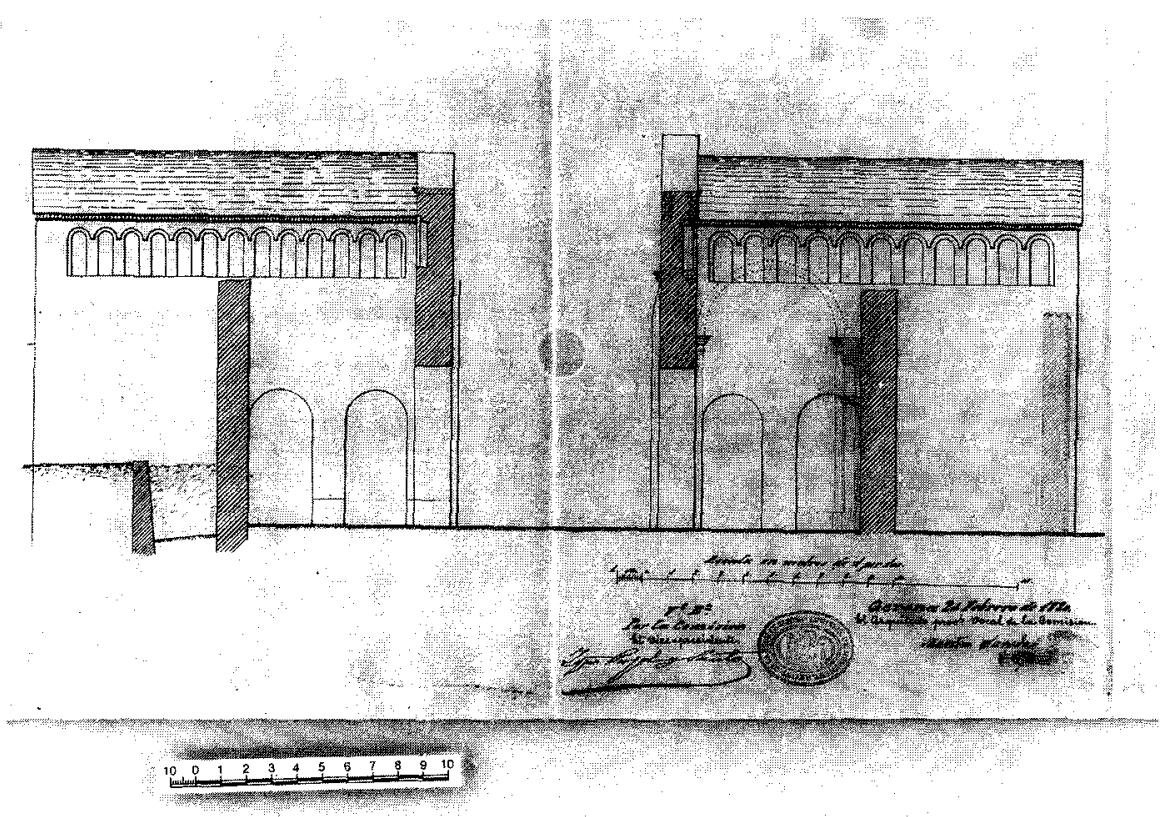

Fig. 11. Martín Sureda. Corte transversal por la línea A.B. de la planta. (1880).
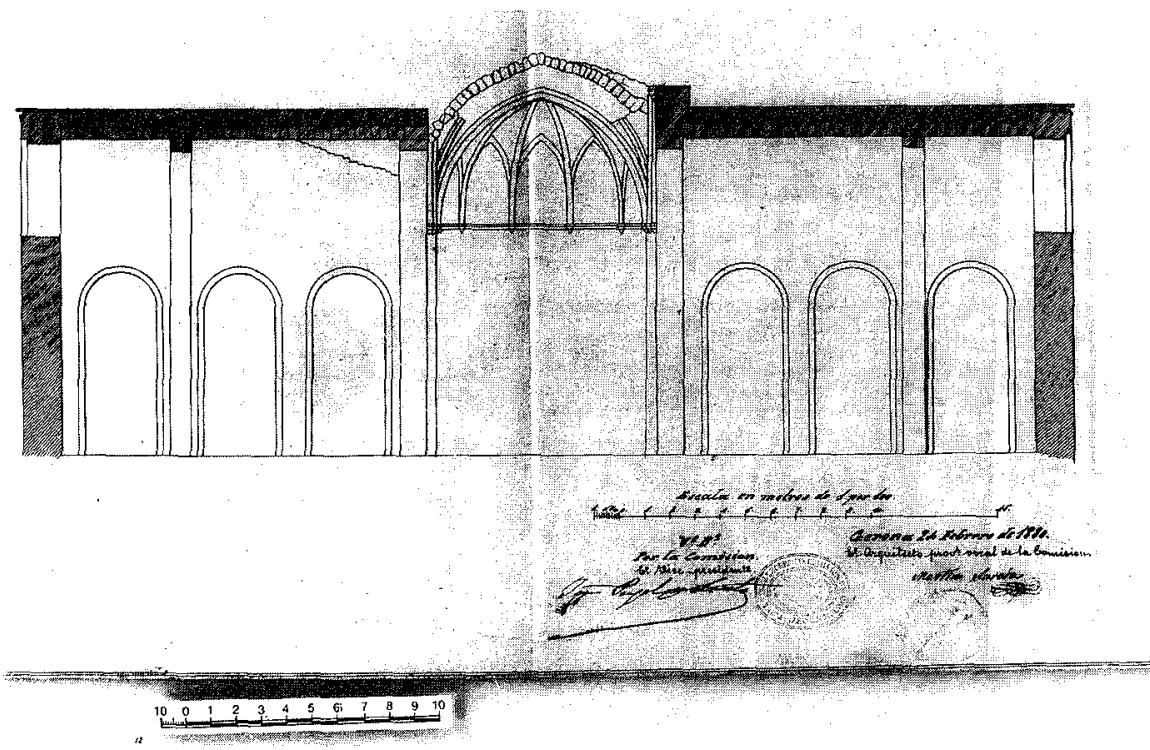

Fig. 12. Martín Sureda. Corte longitudinal del crucero. (1880). 


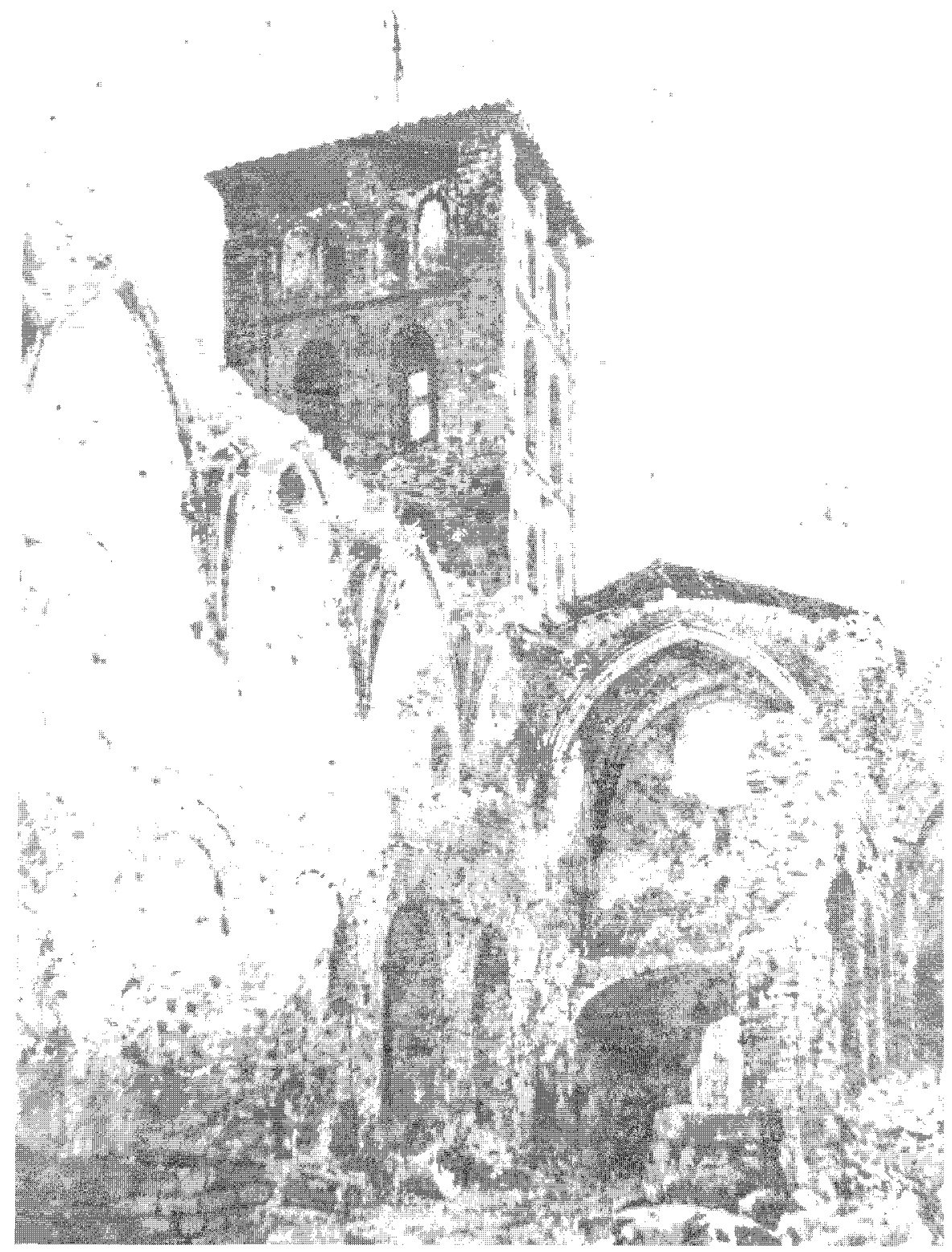

Fig. 13. Soler i Rovirosa. Naves arruinadas de la Iglesia. (1881). 


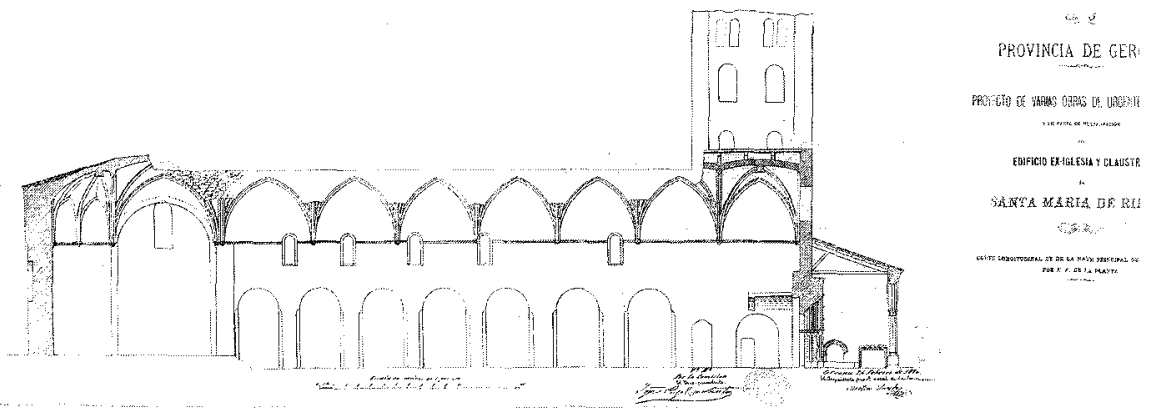

Fig. 14. Martín Sureda. Corte longitudinal de la nave principal por la línea E.F. de la planta. (1880).

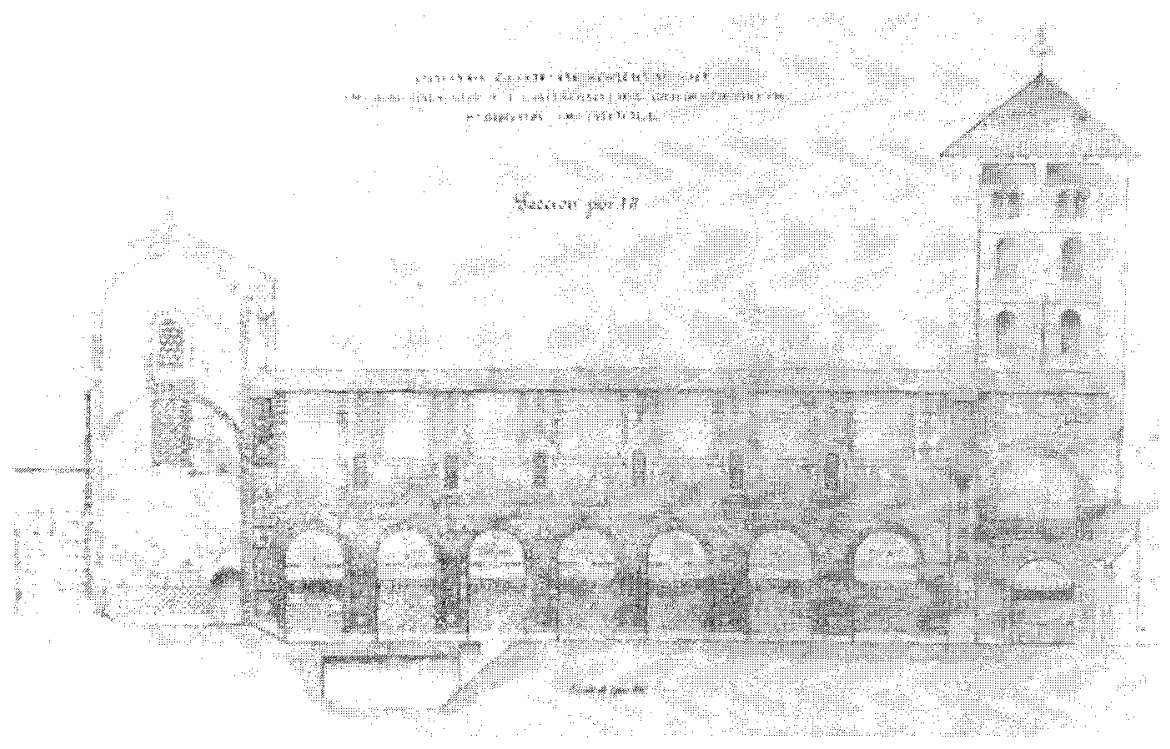

Fig. 15. Elías Rogent. Sección longitudinal de la nave por la línea A.B. de la planta. (1865). 


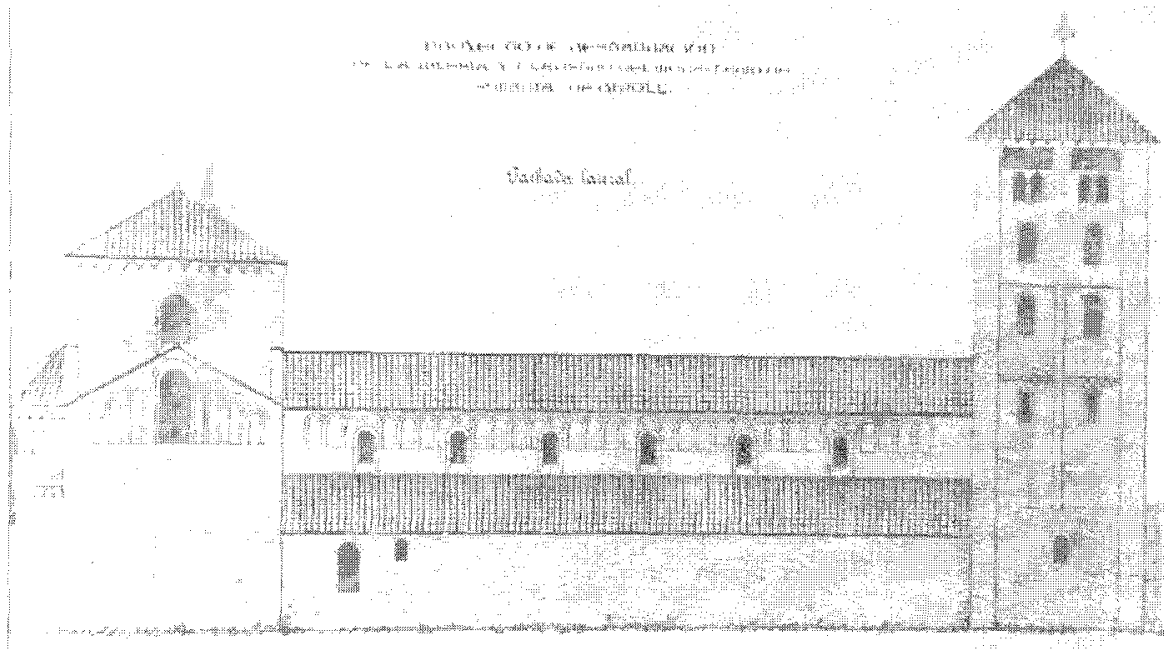

Fig. 16. Elias Rogent. Fachada lateral de la Iglesia. (1865).

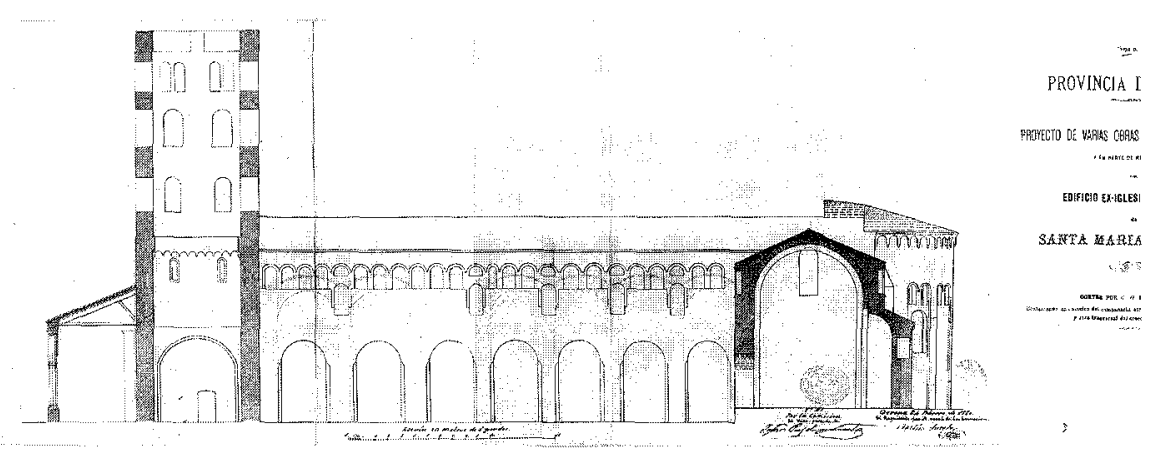

Fig. 17. Martín Sureda. Corte longitudinal por la línea G.H. de la planta. (1880).

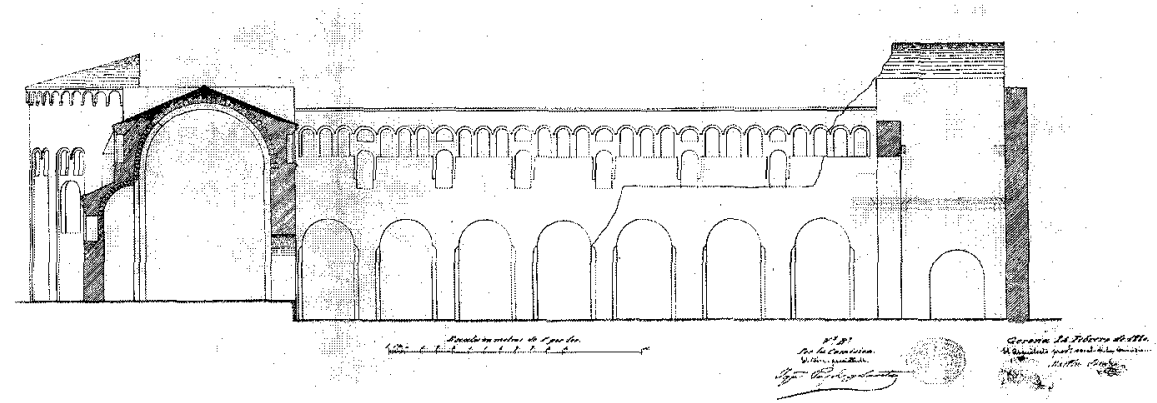

Fig. 18. Martín Sureda. Corte longitudinal por la línea J.K. de la planta. (1880). 


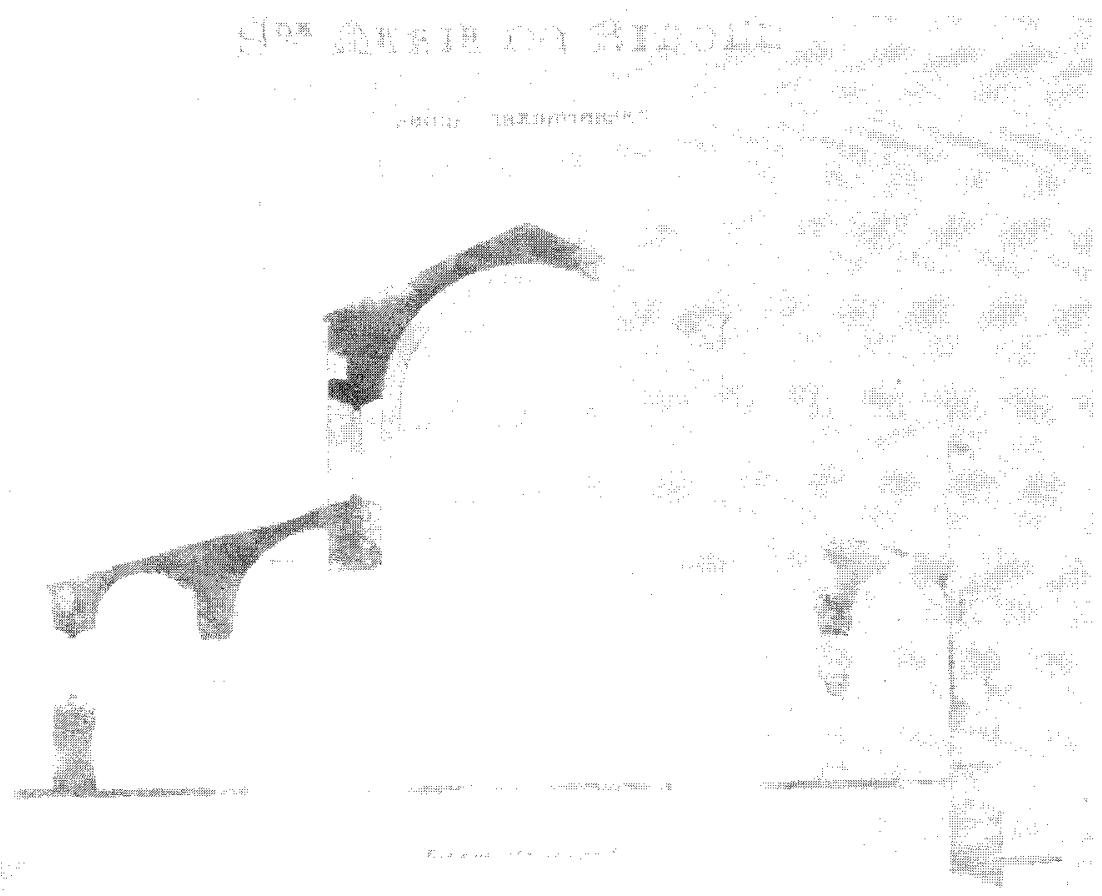

Fig. 19. Elias Rogent. Sección transversal de la Iglesia. (1886).

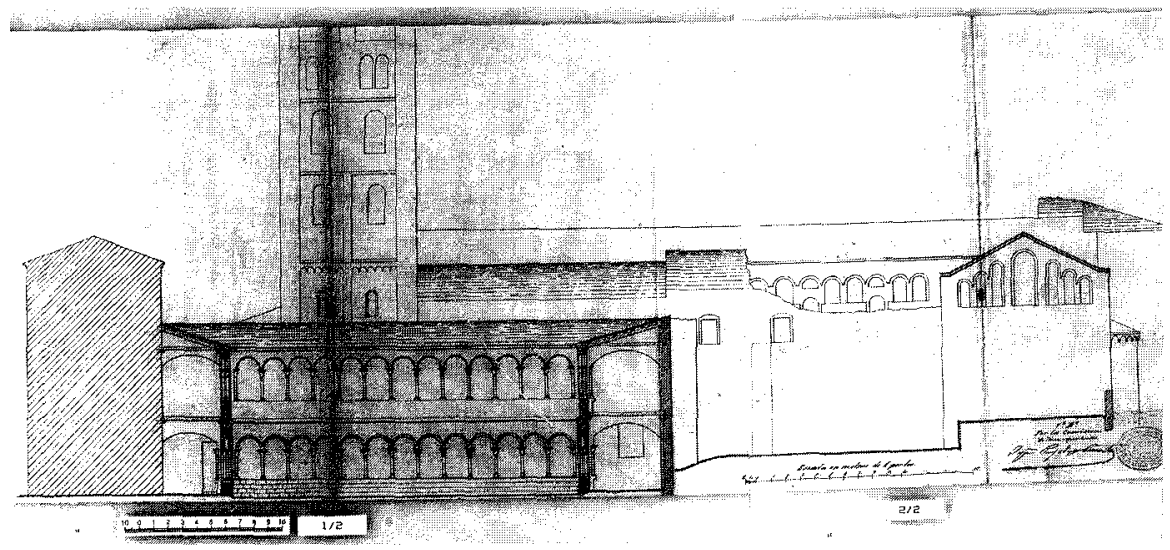

Fig. 20. Martín Sureda. Sección longitudinal por la línea L.M. de la planta. (1880). 

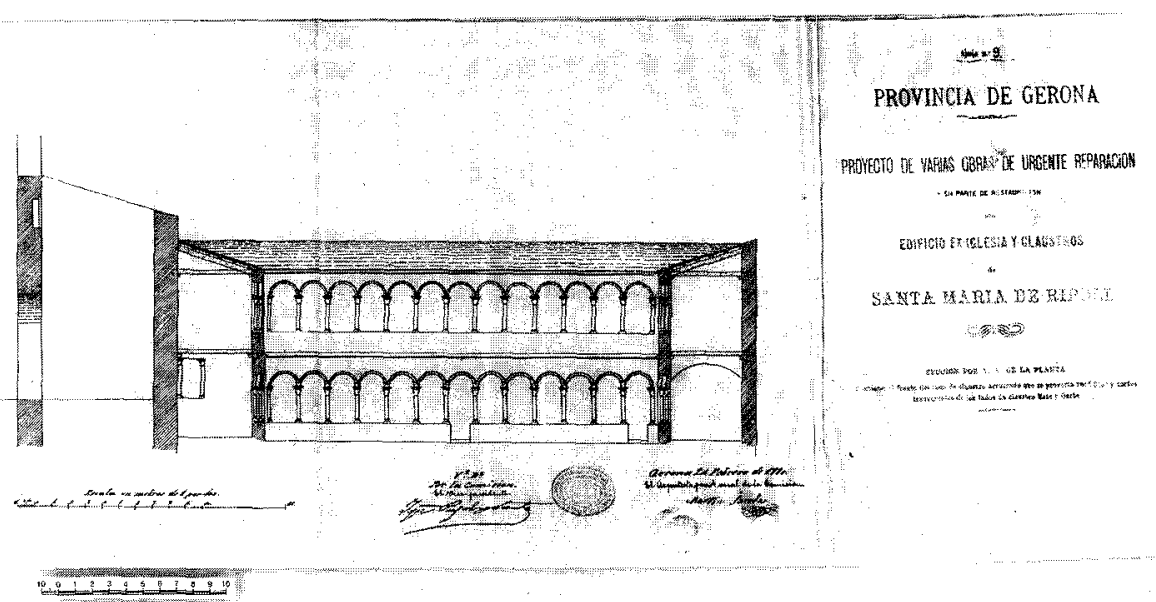

Fig. 21. Martín Sureda. Sección en sentido transversal del claustro por la línea M.. de la planta. (1880).

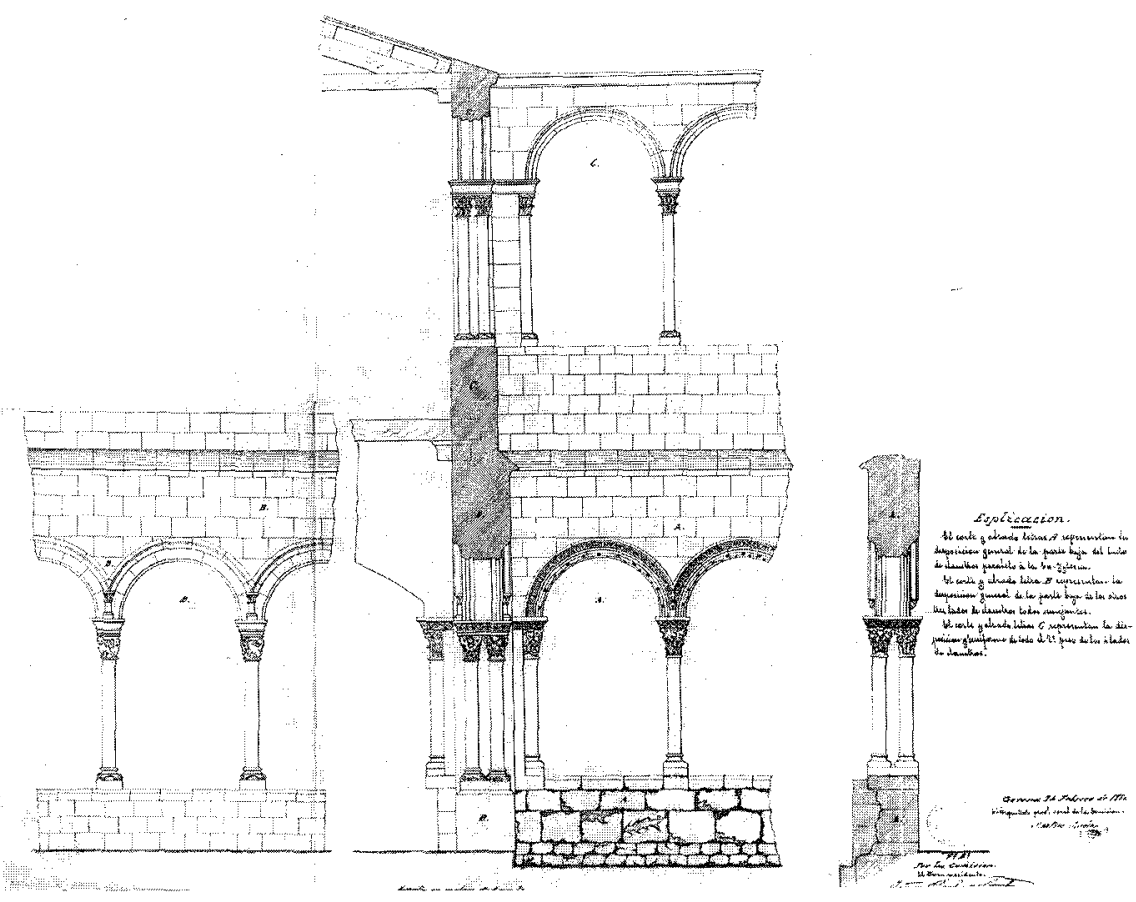

Fig. 22. Martín Sureda. Dibujo de detalles demostrando la disposición general y estilo de las columnatas y arcadas de los cuatro lados del claustro. (1880). 


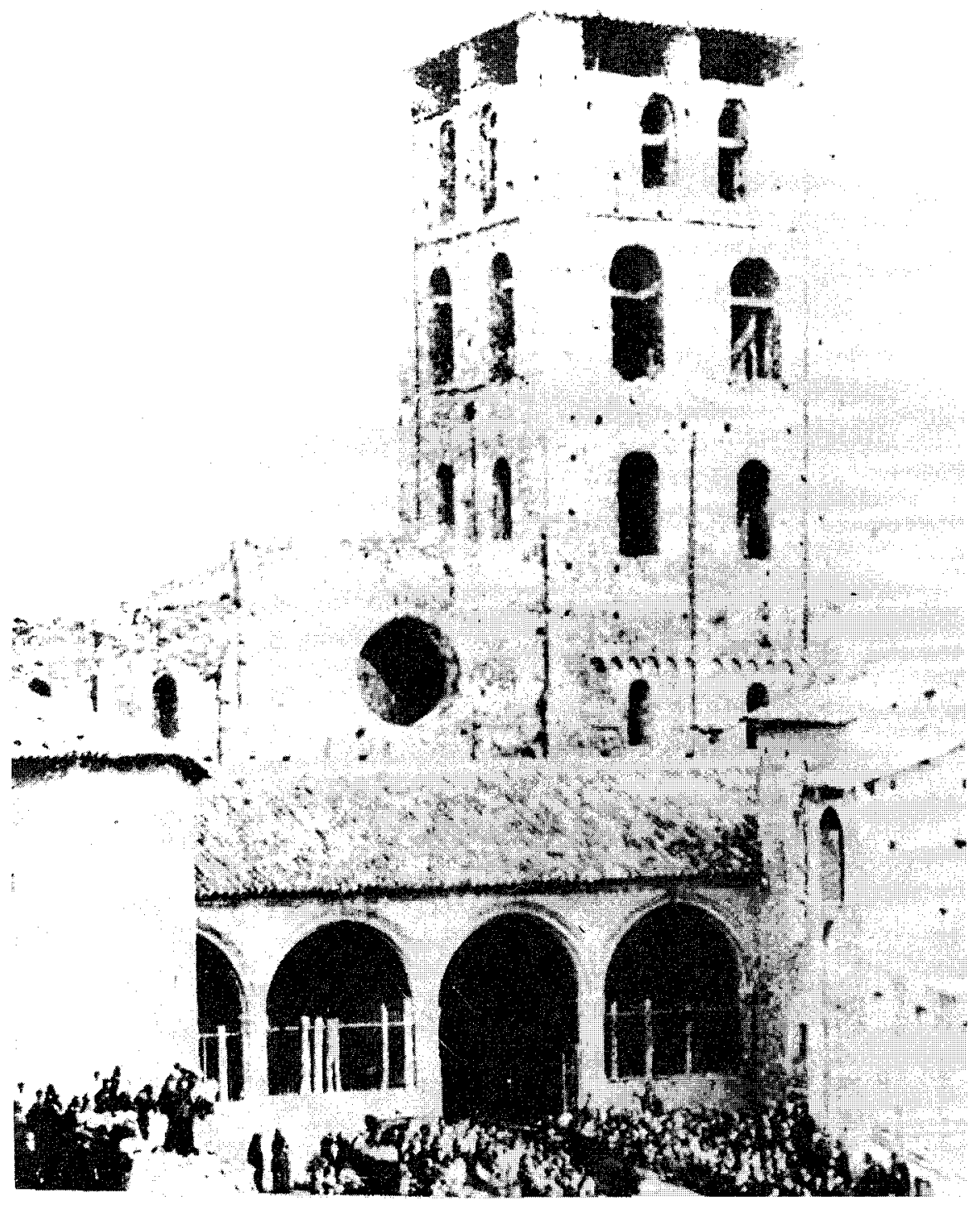

Fig. 23. Estado de la fachada principal de la Iglesia antes de la restauración. 


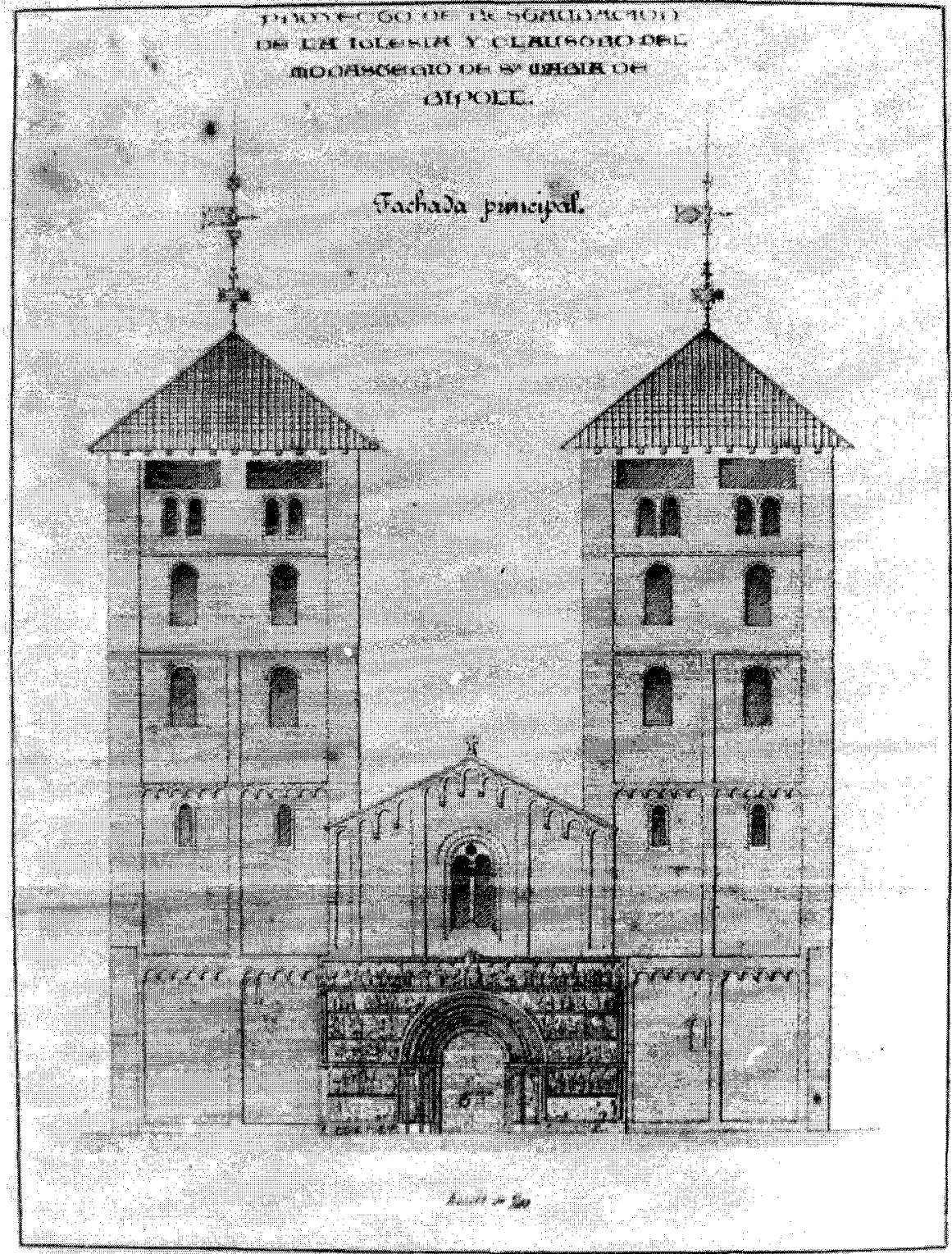

Prmer projecte de restauracio de Sta Maria de Ripoll (186b). Façana prncipa.

Fig. 24. Elías Rogent. Fachada principal. Primer proyecto de restauración. (1865). 


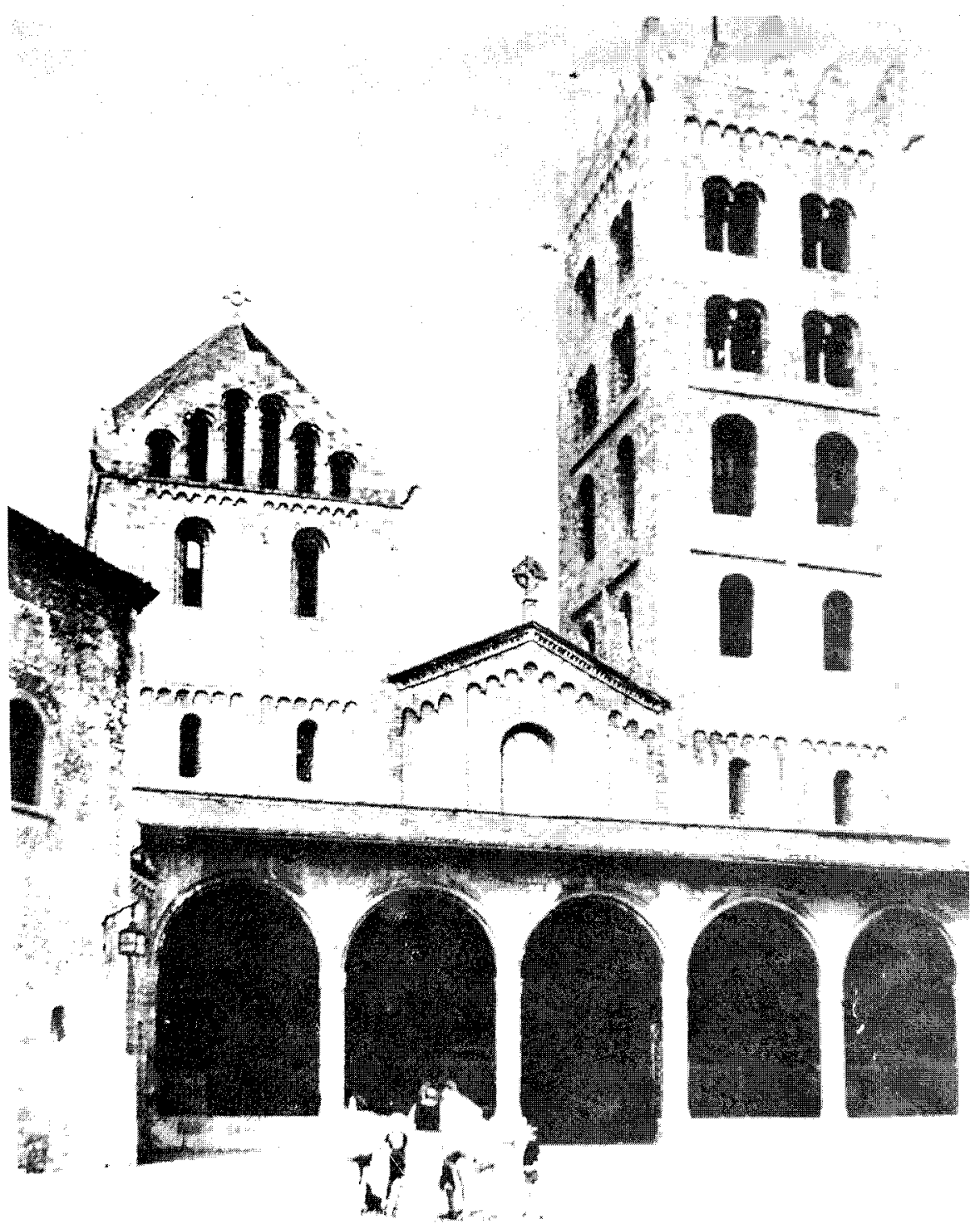

Fig. 25. Estado de la fachada principal de la Iglesia después de la restauración. 